\title{
Mass Shootings and Public Support for Gun Control
}

\author{
BENJAMIN J. NEWMAN AND TODD K. HARTMAN*
}

The recent spate of mass public shootings in the United States raises important questions about how these tragic events might impact mass opinion and public policy. Integrating research on focusing events, contextual effects and perceived threat, this article stipulates that residing near a mass shooting should increase support for gun control by making the threat of gun violence more salient. Drawing upon multiple data sources on mass public shootings paired with large-N survey data, it demonstrates that increased proximity to a mass shooting is associated with heightened public support for stricter gun control. Importantly, the results show that this effect does not vary by partisanship, but does vary as a function of salience-related event factors, such as repetition, magnitude and recency. Critically, the core result is replicated using panel data. Together, these results suggest a process of context-driven policy feedback between existing gun laws, egregious gun violence and demand for policy change.

Keywords: gun control; gun violence; mass shooting; public opinion; contextual effect

We gather here in memory of twenty beautiful children and six remarkable adults. They lost their lives in a school that could have been any school; in a quiet town full of good and decent people that could be any town in America.

-Former President Barack Obama ${ }^{1}$

On 14 December 2012, a young man opened fire on twenty-eight people at Sandy Hook Elementary in Newtown, Connecticut, killing twenty school children and six adult staff members in one of the worst mass public shootings in recent US history. In the weeks that followed, an intense public debate surrounded the issue of gun violence, covering a wide array of topics such as the mental health of attackers, ${ }^{2}$ cultural issues ${ }^{3}$ and violent video games; $;^{4}$ the core political issue was restricting access to firearms. Speaking about the tragedy, former President Obama reminded Americans that Newtown was not an isolated incident; rather, there seemed to be 'an endless series of deadly shootings across the country, almost daily reports of victims, many of them children, in small towns and big cities all across America'. ${ }^{5}$ While the attacks at Sandy Hook and other mass public shootings like those in Aurora, Blacksburg and Littleton make national headlines, there are countless others that receive considerably less attention but are just as devastating to affected communities.

* Department of Political Science, School of Public Policy, University of California, Riverside (email: bnewman@ucr.edu); Sheffield Methods Institute, The University of Sheffield (email: t.k.hartman@ sheffield.ac.uk). We would like to thank Steven Melendez for his help with the data and Figure 1. Data replication sets are available in Harvard Dataverse at: https://dx.doi.org/10.7910/DVN/LL6UTV and an online appendix is available at: https://doi.org/10.1017/S0007123417000333.

1 https://www.whitehouse.gov/the-press-office/2012/12/16/remarks-president-sandy-hook-interfaith-prayer-vigil.

2 Kellerman 2012.

3 Ghose 2012.

4 Jaslow 2013.

5 Jaslow 2013. 
Gun legislation has become a perennial issue in American politics, driven in large measure by the increased media attention and public interest in gun control laws following mass public shootings. A predictable feature of the discourse following mass shootings in the United States is the polarized response by gun rights and gun control activists. On the one hand, powerful gun rights advocates like the National Rifle Association (NRA) claim that these attacks demonstrate the need for more - not less - access to firearms in the hands of qualified professionals. On the heels of the Sandy Hook shootings, NRA Executive Vice President Wayne LaPierre famously said, 'the only thing that stops a bad guy with a gun is a good guy with a gun'. ${ }^{6}$ Second Amendment advocates also point to surges in NRA membership following mass public shootings as evidence of the public's support for their cause. ${ }^{7}$ On the other hand, grassroots gun control groups like the Brady Campaign to Prevent Gun Violence urge lawmakers to heed the millions of dollars in private donations that poured in after Sandy Hook and similar events as a signal that public opinion had shifted in their favor. ${ }^{8}$ Dan Gross, President of the Brady Campaign, pleaded with Congress to acknowledge the growing 'disconnect between what the American public wants on this issue and what [our] elected officials are doing about it'.

When shifting the focus from the responses of elites to the general public, one question of clear importance is whether public opinion is impacted by instances of profound gun violence. Further, compared to citizens living hundreds or even thousands of miles away from a shooting and learning about it through the mass media, there is a relatively large and growing body of Americans who have had their lives personally touched by gun violence by having a mass shooting occur in or near their community. One question yet to be empirically addressed is, for these citizens, does having a mass shooting occur so close to home trigger support for increased government gun control efforts?

While there has been scholarly research on the rate at which mass public shootings have increased in recent decades, ${ }^{10}$ as well as a number of investigations into their causes, ${ }^{11}$ surprisingly, prior scholarship has not examined whether proximity to a mass public shooting affects citizens' gun control policy preferences. We believe this question speaks not only to the broader literature on the role of context in shaping public opinion, but also to the more general issue of 'policy feedback $^{12}$ in mass politics. In other Western nations where mass shootings have occurred, they were swiftly followed by changes in legislation, indicating a prompt degree of policy feedback. For example, the 1996 Dunblane Massacre of sixteen British school children and one teacher led to the passage of two firearms acts and a permanent ban on private handgun ownership in the UK. Likewise, the 1996 Port Arthur Massacre in Tasmania, which left thirty-five dead and twenty-three wounded, led the Australian Government to introduce the National Firearms Agreement that outlawed automatic and semi-automatic weapons, as well as pump-action shotguns. In the United States, however, we have yet to see similar tragedies catalyze significant policy change, which raises the question: why is the United States so resistant to changes in gun legislation?

While some point to our strong culture of gun rights, ${ }^{13}$ and others to polarized responses by elites, ${ }^{14}$ one possibility is that a key link in the policy-feedback chain - public opinion - fails to

${ }^{6}$ http://www.washingtonpost.com/politics/remarks-from-the-nra-press-conference-on-sandy-hook-schoolshooting-delivered-on-dec-21-2012-transcript/2012/12/21/bd1841fe-4b88-11e2-a6a6-aabac85e8036_story.html.

$7 \mathrm{http}: / / \mathrm{www}$.politico.com/story/2013/01/brady-campaign-raises-5m-post-sandy-hook-086157.

$8 \mathrm{http}: / / \mathrm{www}$.politico.com/story/2013/01/brady-campaign-raises-5m-post-sandy-hook-086157.

9 http://www.whatthefolly.com/2012/12/18/transcript-brady-campaign-pres-dan-gross-presses-lawmakers-tosolve-americas-gun-violence-epidemic/.

${ }^{10}$ Cohen, Azrael, and Miller 2014; Krouse and Richardson 2015.

11 Bjelopera et al. 2013; Dutton, White, and Fogarty 2013; Kissner 2016; Langman 2009; Lankford 2016; Lankford and Hakim 2011.

12 Pierson 1993.

13 Cramer 2006; Hofstadter 1970; Melzer 2009; Squires 2000.

14 Spitzer 2011. 
respond to such incidents of extreme gun violence with augmented demand for stricter government regulation of firearms. In this article, we theorize that mass public shootings affect public opinion in a contextually driven manner. Our core hypothesis is that having a mass public shooting occur in close proximity to one's community will lead to increased support for gun control. Germane to this causal expectation is the notion of threat salience: the basic logic is that proximate (versus distal) threats are more salient. Mass public shootings raise the specter of gun violence, and shootings that happen close to home involve known places and potentially known people. In this way, public shootings occurring in close proximity should make gun violence, as well as falling victim to gun violence, more palpable.

Using data from multiple sources on mass public shootings merged with the 2010 Cooperative Congressional Election Study (CCES), we show that increased proximity to a mass shooting is associated with heightened public support for stricter government regulation of firearms. Importantly, we show that this main effect does not vary by partisanship. To demonstrate the robustness of our main finding, we show that this contextual effect is conditional upon additional salience-related factors, such as (1) repeated events, (2) the magnitude of the event (that is, the number of victims), and (3) the recency of events. As a further demonstration of robustness, we offer placebo tests, which show that proximity to a mass shooting fails to exert any effect on 'treatment-irrelevant' policy attitudes (for example, climate change, abortion, gay marriage, etc.). To offer a stronger test of causal effects, we use the 2010-2012 CCES re-interview panel to demonstrate that respondents 'treated' with a mass public shooting occurring near their residence between survey waves were significantly more likely than 'untreated' respondents to shift their opinions towards support for stricter gun control policies. Lastly, we replicate these results with different survey data collected in 2010 by the Pew Research Center. We conclude this article by discussing the substantive implications of our findings, as well as possible directions for future research.

\section{PRIOR RESEARCH ON MASS SHOOTINGS AND PUBLIC OPINION}

To our knowledge, little or no research has directly tested whether mass shootings affect individual opinion towards gun control policy. There has been a great deal of descriptive analysis of polling data about Americans' attitudes towards gun legislation. On the one hand, recent analysis of Gallup and Pew polling data shows that Americans in the aggregate have become steadily less supportive of gun control over the past 25 years, dropping from clear majorities who favored gun control in the 1990 s to less than half of those surveyed by the late $2000 \mathrm{~s} .{ }^{15}$ On the other hand, the polls also reveal spikes in support for gun control that appear to coincide with the mass shootings in Columbine $^{16}$ and Newtown; ${ }^{17}$ however, such spikes quickly regressed to the steady pattern of declining support seen throughout the full time series. In sum, this largely descriptive body of research suggests that American public opinion may be responsive to certain high-profile mass shootings (e.g., Sandy Hook), but that such responses represent brief bursts of opinion change that do not endure. More importantly, the aggregate nature of the analyses contained in this work, along with the relative absence of panel studies, limits its ability to determine whether there are any real shifts in individual attitudes towards gun control following mass public shootings.

Research investigating how the media cover mass public shootings is more abundant in the scholarly literature. Much of this literature focuses on examining the volume and patterns of

15 Doherty 2015; Enten 2015; Wheldon 2015; Wozniak 2015.

16 Smith 2002.

17 Wozniak 2015. 
news coverage regarding specific high-profile mass attacks, ${ }^{18}$ the majority of which demonstrate how the 1999 Columbine school shooting dominated news coverage, and by implication, brought the issue of gun violence to the top of the national policy agenda. ${ }^{19}$ Some research provides causal evidence that media frames about gun control affect policy attitudes. For example, Haider-Markel and Joslyn ${ }^{20}$ find that support for concealed carry laws declines when the issue of carrying handguns is framed as a potential threat to public safety (versus as a matter of constitutional rights). Moreover, McGinty, Webster and Barry ${ }^{21}$ find that respondents supported restricting access to firearms for the mentally ill, as well as banning large-capacity magazines, following exposure to news stories highlighting these specific issues. Together, this body of work suggests the possibility of policy feedback in the form of public demand for gun control in response to mass shootings, albeit such feedback appears highly contingent upon issue framing.

This body of media-centered research on mass shootings is strongly predicated upon viewing mass shootings as something Americans experience indirectly through media imagery and discourse. Yet the sheer volume, not to mention the increasing rate and geographic spread, of mass public shootings in the United States suggests looking beyond such pretenses, as there is an ever-growing subset of the American public that is personally touched by gun violence due to residing in, or near, a location where a mass shooting has occurred. For these citizens, the mass media is not the primary vehicle for experiencing egregious gun violence. Furthermore, when conceptualizing mass public shootings as a treatment delivered through the mass media, it is important to recall that many Americans fail to pay attention to the news and public affairs, ${ }^{22}$ and among those who do pay attention, there is a pronounced tendency for selective exposure to partisan news. ${ }^{23}$ In other words, there is variation in receipt of the treatment, as well as heterogeneity in the content of the treatment; each suggests a limited real-world meaning of framing effects observed through forced exposure in experimental contexts.

In sum, the limitations in the existing social science literature on the impact of mass public shootings, and gun violence more generally, on public opinion suggest looking beyond descriptive analyses of aggregate data, as well as beyond variation in media coverage and frames. What is distinctly missing is research focusing on another important form of variation in exposure to gun violence via mass public shootings - spatial variation in proximity to where these events occur. Indeed, the literature currently lacks any investigation of whether exposure to mass shootings via proximity to where they occur is systematically related to citizens' views on gun control. Nor has there been a study of whether individuals change their opinions over time in response to exposure to a mass shooting.

\section{MASS SHOOTINGS IN CONTEXT: PROXIMITY AND THE SALIENCE OF GUN VIOLENCE}

Three bodies of research provide a foundation for the expectation that living close to a mass shooting should influence preferences for gun control: (1) studies examining the impact of events on political attitudes, (2) a large and growing body of research on context and public opinion and (3) the political psychology literature on threat.

${ }^{18}$ E.g., Muschert and Carr 2006; Maguire, Weatherby, and Mathers 2002.

19 Altheide 2009; Chyi and McCombs 2004; Lawrence and Birkland 2004; Muschert 2009.

${ }^{20}$ Haider-Markel and Joslyn 2001.

${ }^{21}$ McGinty, Webster, and Barry 2013.

22 Graber and Dunaway 2014.

23 Arceneaux, Johnson, and Murphy 2012. 
Scholars have long argued that prominent societal events can exert profound and lasting effects on citizens' political attitudes and behavior. ${ }^{24}$ For instance, Sears and Valentino ${ }^{25}$ find that exposure to high-intensity campaign events increases attention to politics among those who might otherwise be apathetic, and crystalizes opinions on issues covered prior to the election. Other scholars have found that extraordinary events like the assassination of President John F. Kennedy, ${ }^{26}$ Hurricane Katrina ${ }^{27}$ and the $9 / 11$ attacks $^{28}$ can indelibly alter evaluations of government, policy preferences, and a wide array of political attitudes and behaviors. Even local events, like the Watts Riots in Los Angeles, have been shown to influence the opinions of those living in the area. ${ }^{29}$ In sum, these 'focusing events' highlight the need for legislative action by providing a stark example of why a particular policy proved ineffectual or out of line with public opinion. ${ }^{30}$ In other words, focusing events provide citizens with an opportunity 'to observe and evaluate government in action, ${ }^{31}$ and thus create opportunities for feedback in the policy-making process. Sears ${ }^{32}$ argues that 'one criterion for assessing the robustness of a democracy is whether or not the citizenry responds sensibly to ongoing political events'.

One important consideration in thinking about the impact of events is their spatial component, as many potentially impactful events occur at specific locations (for example, protests) or exert their impact differentially across local areas (for example, natural disasters). Indeed, over the past decade there has been renewed scholarly interest in investigating how residential context affects policy preferences and voting behavior, ${ }^{33}$ and this literature strongly suggests that the consequences of extraordinary events should be contextually dependent. ${ }^{34}$ For example, with respect to environmental disasters, Bishop ${ }^{35}$ demonstrates that, while the Deepwater Horizon oil spill may have encouraged some people to favor stricter environmental regulations following the disaster, nearby residents whose communities directly benefited from the oil industry were more likely to support drilling even after the spill. Focusing on natural disasters, Velez and Martin ${ }^{36}$ show that the Obama administration's acuity in preparing for Hurricane Sandy resulted in the strongest gain in votes among citizens residing in areas most devastated by the hurricane. Turning to race-relevant events, Enos ${ }^{37}$ finds that the large-scale demolition of public housing projects in Chicago, which resulted in the residential displacement of large numbers of African-American city residents, only impacted the voting behavior of white voters residing in close proximity to demolished buildings. Additionally, Hopkins ${ }^{38}$ finds that events related to immigration (for example, the North American Free Trade Agreement, the Elian Gonzalez controversy, etc.) led to increases in anti-immigrant sentiment only among citizens residing in areas experiencing growth in immigrant populations. Lastly, Newman demonstrates that the 2008 Financial Crisis instigated perceptions of corporate profiteering and

24 Sears 2002.

25 Sears and Valentino 1997.

26 Sears 1965; Sheatsley and Feldman 1964; Sheatsley and Feldman 1965.

27 Atkeson and Maestas 2012; Huddy and Feldman 2006.

28 Huddy and Feldman 2011; Jacobson 2007; Smith, Rasinski, and Toce 2001; Traugott et al. 2002.

29 Sears and McConahay 1973.

30 Birkland, 1996; Birkland 1997; Birkland 1998; Birkland 2006; Kingdon 1984.

31 Atkeson and Maestas 2012, 4.

32 Sears 2002, 250.

33 Cho and Gimpel 2012; Rogers 2014; Wong 2010.

34 Bishop 2014; Enos 2016; Hopkins 2010; Newman 2015.

35 Bishop 2014.

36 Velez and Martin 2013.

37 Enos 2016.

38 Hopkins 2010. 
maldistribution only among citizens residing in economically depressed areas. ${ }^{39}$ In short, the growing body of contextual research highlights the importance of situating events in space in order to understand the effects of prominent events such as mass public shootings on public opinion.

While each of these studies concerns unique events and different policy domains, the common thread of this research is that the 'focusing' quality of prominent events should vary as a function of one's proximity to the event. As focusing events are theorized to increase awareness, information, and the formulation or updating of opinions about event-relevant issues, the contextual literature suggests that these processes should be more pronounced for citizens residing in close proximity to events. Beyond informational effects, two additional important components of proximity are tangibility and salience: being close to an event should make the forces, issues and - most importantly for our purposes - the threats it poses more palpable and exigent. The effect of the $9 / 11$ attacks, for example, was undeniably more tangible for individuals living and working in lower Manhattan, as well as for residents of the Tri-State Area. Numerous studies demonstrate that those living within a 100-mile radius of the World Trade Center reported considerably higher levels of psychological distress and signs of posttraumatic stress disorder than those living farther away from the epicenter of the attacks. ${ }^{40}$ While the mass media may draw attention to extraordinary events on the national stage, those residing close to a specific event should be more personally touched by it. This is especially important when the events in question involve a threat to property or well-being, such as with natural and environmental disasters, public health disasters, or incidents of random and egregious gun violence. In short, those residing closer to destructive events should have a more palpable experience of the incident, a heighted perception of threat and an increased sense of the risk of future victimization.

Thus the literature on perceived threat and anxiety helps us explain one potential mechanism through which proximity to mass shootings may impact their salience. First, we know that humans are acutely attuned to threatening stimuli in their environment. ${ }^{41}$ Yet we also know that not all threats are created equal, and reactions to threatening stimuli should differ depending on the specific type of threat encountered. For instance, Huddy and colleagues have argued that it is necessary to distinguish between general threats to the nation and personal threats to the individual; the latter increase feelings of personal vulnerability and motivate self-protective action. ${ }^{42}$ Personal threat, which arises from proximate physical danger, is likely to elicit more anxiety than remote threats to the nation. ${ }^{43}$ For instance, approximately 75 per cent of New Yorkers were worried that they or their family members would be the victim of a future attack, compared to only 31 per cent of all Americans, in the weeks after the $9 / 11$ attacks. ${ }^{44}$ Others have found that those living in the Northeast expressed greater anxiety and felt more personally threatened by terrorism after 9/11 than Americans living in other regions of the country. ${ }^{45}$ In addition, social or psychological proximity in the form of knowing someone who was victimized by a terrorist event heightened the sense of personal vulnerability and feelings of anxiety after $9 / 11 .^{46}$ In this sense, mass public shootings should serve as extraordinary focusing

39 Newman 2015.

40 Schlenger et al. 2002; Schuster et al. 2001.

41 Dijksterhuis and Aarts 2003; Marcus, Neuman, and MacKuen 2000.

42 Huddy et al. 2002; Huddy et al. 2005; Huddy and Feldman 2011; Huddy, Feldman, and Cassese 2007; Huddy, Feldman, and Weber 2007.

43 Huddy et al. 2002; Huddy et al. 2005.

44 Huddy et al. 2002.

45 Skitka, Bauman, and Mullen 2004.

46 Huddy et al. 2005; Huddy et al. 2007. 
events that increase feelings of personal threat and anxiety among nearby residents, thus triggering the brain's 'surveillance system'. ${ }^{47}$ These feelings of threat and anxiety, in turn, should motivate individuals to seek out information about the issue and to support actions that would reduce the threat of victimization by gun violence.

To summarize, the literature on focusing events suggests that a catastrophe like a mass shooting should increase public scrutiny of the issue of gun violence, as well as highlight the need for legislative action to remedy the problem. The research on contextual effects highlights the spatial component of mass shootings - that is, individuals residing in or near targeted communities bear the brunt of the tragedy, and by implication, should manifest more acute effects than those living farther away. Finally, the scholarly work on perceived threat suggests that individuals should respond to personally threatening stimuli with heightened vigilance, searching for ways to mitigate the danger and reduce feelings of vulnerability. Taken together, these three bodies of work lay a strong foundation for the expectation that proximity to a mass public shooting should make the threat of gun violence more palpable and salient, which in turn should stimulate demand for greater government restrictions on access to firearms. We translate this expectation into the core hypothesis of this article:

HYPOTHESIS 1 (Proximity Hypothesis): Living in close proximity to a mass public shooting should generate support for gun control.

One important issue to address is possible heterogeneity in citizens' interpretation of (and response to) events. Hypothesis 1 suggests that proximity to mass shootings should make the threat of gun violence more salient to all nearby residents irrespective of their previous attitudes or partisan leanings, and that this should increase support for gun control generally. This expectation is supported by research demonstrating that perceived threats affect policy preferences independently of partisanship, political ideology or even personality traits such as authoritarianism. ${ }^{48}$ One alternative, however, is that the motivation to maintain one's previously held beliefs about gun control influences how one interprets mass shootings. ${ }^{49}$ Prior attitudes and partisanship are strong motivational factors in citizens' political reasoning, ${ }^{50}$ and may cause divergences in perceptions of culpability for mass shootings and beliefs concerning the subsequent reduction of risk.

Thus, there could be differences in how partisans perceive the issue of gun control, and polls show that Democrats and Republicans approach the issue from vastly difference perspectives. ${ }^{51}$ While most citizens seem to agree that gun violence is a problem, they strongly disagree about how best to reduce such atrocities. ${ }^{52}$ On the one hand, Democrats support gun control policies, which they believe will limit access to dangerous firearms, and by extension, reduce the likelihood of becoming a victim of a mass public shooting. Republicans, on the other hand, prefer policies that allow law-abiding citizens to carry firearms (concealed or otherwise) for their own self-defense. They argue that the only way to deter the use of force is by meeting that force head on. This partisan argument fits well with existing theories on motivated reasoning. ${ }^{53}$ In short, countering our principal hypothesis, an important counterhypothesis predicts that the effect of proximity to mass public shootings will be conditional upon partisanship, with left-leaning citizens potentially

${ }^{47}$ Marcus, Neuman, and MacKuen 2000.

${ }^{48}$ Huddy et al. 2005; Kam and Kinder 2007; Merolla and Zechmeister 2009.

49 Joslyn and Haider-Markel 2013.

50 Lodge and Taber 2000; Taber and Lodge 2006.

51 Pew Research Center 2012; PublicMind 2015; Silver 2012.

52 Craighill and Clement 2015.

53 Kunda 1990. 
becoming more supportive of gun control but right-leaning citizens either evincing no effect or becoming less supportive. This leads to the following hypothesis:

HYPOTHESIS 2 (Partisan-Motivated Reasoning Hypothesis): Proximity to a mass public shooting should generate support for gun control among citizens identifying with the political left (Democrats), but not among those identifying with the political right (Republicans).

\section{DATA AND METHODS}

As an initial test of our hypotheses, we draw upon the 2010 CCES - Common Content. ${ }^{54}$ In addition to offering the benefit of a very large national sample of adult Americans $(\mathrm{N}=55,400)$, the 2010 CCES includes (1) a measure of respondents' preferences towards government regulation of firearms, (2) a range of essential control variables and (3) county Federal Information Processing Standards (FIPS) and zip codes for all respondents. The provision of geocodes enables us to locate respondents spatially, to allow us to test whether reported preferences for gun control are systematically related to the proximity of respondents' place of residence to mass public shootings. The dependent variable for this analysis is a standard gun control question: 'In general, do you feel that laws covering the sale of firearms should be made more strict, less strict, or kept as they are? From this item, we constructed an ordinal variable recoded to range: (1) 'Less strict' [19 per cent], (2) 'Kept as they are' [39.4 per cent] and (3) 'More strict' [41.6 per cent].

To measure our primary predictor - proximity to a mass public shooting - we first had to identify all known mass shooting events in the nation. For this task, we identified three different data sources: (1) the Stanford Geospatial Center's 'Mass Shootings in America' project, ${ }^{55}$ (2) USA Today's 'Behind the Bloodshed' mass killing database ${ }^{56}$ and (3) Mother Jones' 'A Guide to Mass Shootings in America' database. ${ }^{57}$ The differences between these databases are nuanced and revolve around whether (1) the database included events in which victims were killed only with guns or with other weapons (explosives, knives, motor vehicles, etc.), (2) the targets of the attack were family, government or random members of the general public, (3) the cut-off for being defined as a 'mass' event was 3, 4 or more than 4 people injured or killed, and (4) the time frame of the data collection.

We combined results from these databases into a single dataset, ${ }^{58}$ retaining cases involving (1) firearms as the primary weapon used, (2) attacks on non-family members of the general public and (3) attacks in which at least three or more individuals were injured or killed. ${ }^{59}$ Thus our 'treatment' of interest is exposure to incidents where a shooter opened fire in a public place

\footnotetext{
54 Ansolebehere 2012. The 2010 CCES was conducted over the internet by YouGov/Polimetrix between October and November. The CCES employs a matched random sample methodology, and achieved an AAPOR response rate (definition 3) of 41.8 per cent. For more information about this survey, please see Ansolebehere (2012).

55 Data available at: https://library.stanford.edu/projects/mass-shootings-america.

56 Data available at: http://www.gannett-cdn.com/GDContent/mass-killings/index.html\#title.

57 This data can be obtained here: http://www.motherjones.com/politics/2012/07/mass-shootings-map.

58 One benefit of combining these data sources is that it increases the exhaustiveness of our data. For example, these databases rely upon different sources of information, with the Stanford data relying on online reports and the USA Today data relying on FBI reports. Additionally, we benefit from the efforts by these agents to enhance existing data sources, as is the case with the USA Today data, where FBI reports were enhanced where lacking, such as in the event of data errors or missing cases. Replication data and code are available at the Harvard Dataverse: https://dx.doi.org/doi:10.7910/DVN/LL6UTV.

59 We use these criteria because our primary interest is in mass public shootings, so we exclude mass killing incidents not involving the use of firearms, where the victims were all family members, and other gang- or drugrelated shootings.
} 


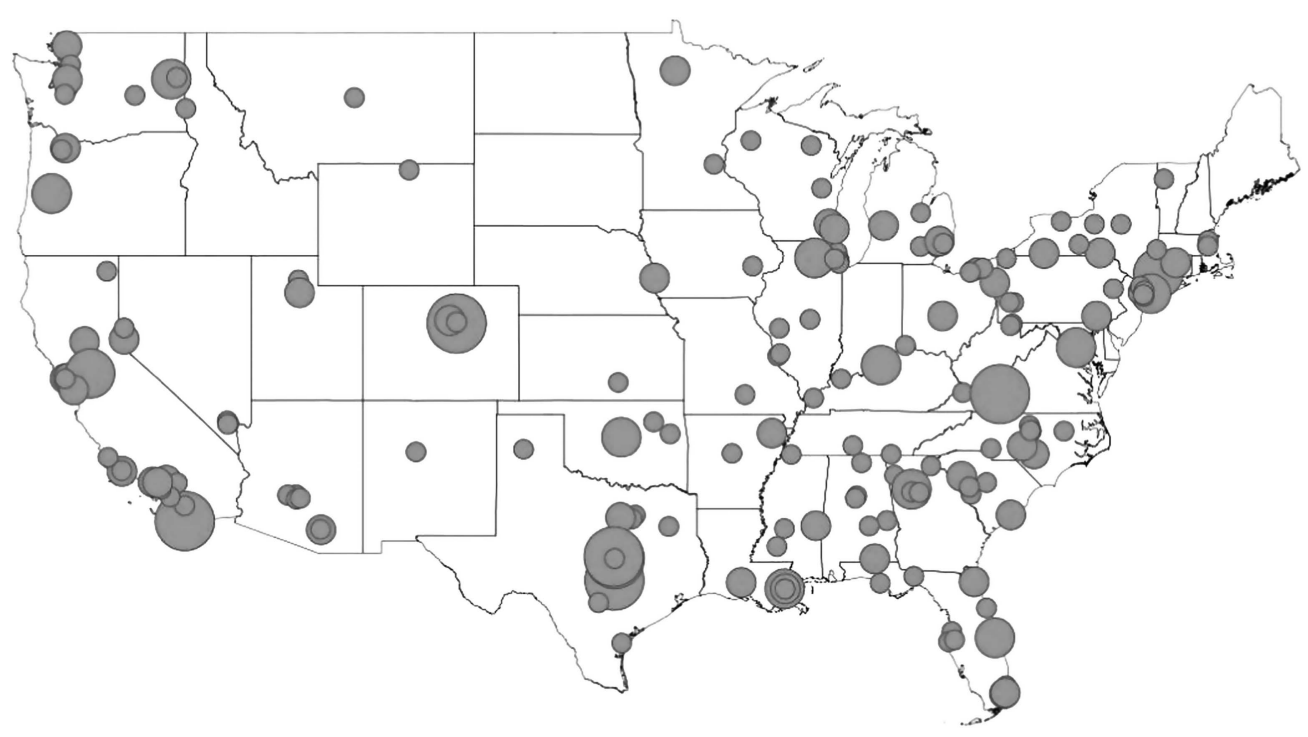

Fig. 1. Location of mass public shootings in the continental United States, 1966-2015

Note: the size of the circle marker corresponds to the number of injured and killed. The map was created in TileMill $^{\circledR}$, with state lines drawn from 2014 cartographic boundary shapefiles from the US Census Bureau (https://www.census.gov/geo/maps-data/data/cbf/cbf_state.html).

(for example, school, shopping mall, movie theater, church, etc.) targeting seemingly random members of the public. Using these restrictions, we were left with a database containing $\mathrm{N}=210$ mass public shooting events between 1966 to 2015; 50 per cent of these events occurred after 2007, and 75 per cent of these cases occurred after 1994. Therefore we see that mass shootings have been increasing over time, particularly over the past 15 to 20 years. ${ }^{60}$ The average number killed in these events was 4.5 people $(\min =0, \max =33$ [Virginia Tech Shooting]), and the average number injured (excluding those killed) was 5 ( $\mathrm{min}=0$, $\max =58$ [Movie Theater Shooting in Aurora, CO]). Figure 1 presents a map of this data, which marks each event's location and varies the size of the markers according to the number of persons injured or killed.

Using this data, we constructed a measure labeled Proximity to Shooting, which captures the distance in miles between the centroid of a respondent's zip code of residence and the exact location of the nearest mass shooting event. ${ }^{61}$ Since we match this data with 2010 CCES data, we constructed the distance variable using mass shootings that occur beginning in 1966 and concluding in October 2010 (when the 2010 CCES data collection commenced). Thus for each

${ }^{60}$ While it is possible that earlier incidents of mass public shootings have been missed or under-reported in the databases we utilize, all of the available evidence suggests that these types of events are increasing in frequency. For instance, the FBI conducted a comprehensive review of active shooter incidents and concluded that mass public shootings having been increasing annually since 2000 (Blair and Schweit 2014).

61 Zip code locations were obtained from the US Census Bureau's Zip Code Tabulation Area Cartographic Boundary Files (https://catalog.data.gov/dataset/2014-cartographic-boundary-file-5-digit-zip-code-tabulationarea-for-united-states-1-500000). Zip code centroids were computed using the ST_Centroid function from PostGIS (http://www.postgis.org/), the geographical extensions to the open source PostgreSQL open source database engine (http://www.postgresql.org/). Distances between zip code centroids and shooting locations were computed using the ST_Distance function from PostGIS. 
respondent, this measure captures the distance between their (relatively approximate) place of residence and the nearest mass shooting. Importantly, for ease of interpretation of the results, we recoded this variable to range from farther to closer (in miles) to an event. The mean distance nationally (within the 2010 CCES) is 84 miles (54 miles), with a standard deviation of 112 miles (55 miles). The range of this variable in the CCES data is 870 to 0 miles, indicating some respondents lived as far as 870 miles away from the nearest shooting event, while some respondents lived in a zip code housing one or more mass shootings. ${ }^{62}$ Our analysis includes controls for standard contextual and individual demographic variables, as well as key contextual variables that in theory may influence both (1) the location of mass shooting events and (2) respondents' preferences over gun control policy. At the contextual level, our analysis includes zip code-level controls for median income, rates of college education, racial composition, population density and total population. ${ }^{63}$ To separate out the effect of proximity to a mass shooting from variation in the occurrence of murders more generally, we include a control for the Murders Per Capita in a respondent's county of residence. ${ }^{64}$ It is also possible that the number of firearms in the local area influences the likelihood of a mass shooting and attitudes toward gun control. Thus, we control for Firearm Stores Per Capita within a respondent's county. ${ }^{65}$ Next, we include a control for Republican Vote in respondents' county of residence, ${ }^{66}$ as the level of liberalism versus conservatism in an area may influence the occurrence of mass shootings and is likely correlated to individual residents' views on gun control. Last, as mass shootings tend to cluster in certain states (for example, California, New York, Texas, Washington, Colorado), we control for the number of shootings in a respondents' state of residence (Shootings in State) to ensure that proximity to a mass shooting is not simply capturing residence in a state with more shooting events.

A few descriptive statistics are worth discussing. First, we find moderate negative correlations between Proximity to Shooting and Republican Vote $(\mathrm{r}=-0.28)$ and Firearm Stores Per Capita $(\mathrm{r}=-0.38)$, and weak positive correlations with zip code Population Density $(\mathrm{r}=0.21)$, Median Income $(\mathrm{r}=0.15)$ and College Education $(\mathrm{r}=0.15)$. Thus, rather than mass shootings being entirely random events, they instead appear to be slightly more likely to occur in liberal, semi-urban settings where guns are seemingly less prevalent. The possibility that these variables even remotely predict where shootings occur increases the importance of their inclusion as controls, as each factor is also plausibly linked to views on gun control.

Turning to the individual level, our analysis includes standard demographic controls (education, income, age, gender, race and residence in the South), as well as dummy variables for Homeowners and respondents with Children, as it is possible that owning a home or having children alters views on home safety and gun control. We include dummy variables for whether a respondent is enlisted in the Military, or whether they report being from a Military Family, as it is likely that individuals in the service, or with family members in the service, hold more

62 When excluding Hawaii and Alaska, the range of this variable narrows from 0 to 377 miles.

63 These data are from the US Census Bureau's 2007-2011 American Community Survey 5-Year File.

64 This measure was constructed from the 2008 FBI Uniform Crime Report county 'Reported Offenses' data (http://www.icpsr.umich.edu/icpsrweb/NACJD/studies/27644). Murders Per Capita is the total number of murders in a county divided by the total population.

65 This measure was constructed from the January 2010 'Listing of Federal Firearms Licensees' from the Bureau of Alcohol, Tobacco, Firearms and Explosives (https://www.atf.gov/firearms/listing-federal-firearmslicensees-ffls-2015). It is the total number of licensed firearm vendors in a county divided by the total population.

${ }^{66}$ Republican Vote is the percent of votes in the 2008 presidential election in each county going to John McCain (R). This data is from David Leip's Atlas of US Presidential Elections (http://uselectionatlas.org/). 
favorable views towards gun rights. Last, we include controls for political and symbolic orientations (Party ID, Ideology and Religiosity), as these variables are known to influence a range of views on key political issues, including gun control. For more information about question wording and variable measurement, see Appendix A.

\section{RESULTS}

Given the ordinal nature of our dependent variable, as well as the hierarchical structure of our data (individual respondents embedded within zip codes), we estimated multilevel orderedlogistic regression models with random intercepts for zip code. The results from our analysis are presented in Column 1 of Table 1 . As can be seen, the results strongly align with expectations, as an increase in proximity to a mass public shooting is associated with a significant increase in support for stricter gun control laws $(\beta=0.334$, s.e. $=0.172, \mathrm{p}<0.05) .{ }^{67}$

The size of this effect is displayed in Figure 2, which presents the first differences in the predicted probability of supporting stricter gun control laws associated with a change in Proximity to Shooting. The first plotted coefficient (labeled 'Proximity') indicates that going from respondents residing in zips the furthest away $(\operatorname{Pr}(\mathrm{Y})=0.322)$ to those housing a mass shooting $(\operatorname{Pr}(\mathrm{Y})=0.394)$ is associated with a 0.072 increase in the probability of desiring stricter gun regulations. One way of conceptualizing this effect is with an analogy to experimental research where the estimated quantity of interest is the difference in an outcome between the treated and untreated. In our case, respondents residing furthest away from a mass shooting reside in the state of Alaska, which is spatially separated from the continental US and did not experience a mass public shooting during the 1966 to 2010 time period. ${ }^{68}$ Thus, the comparison between respondents in this zip code and those in zip codes housing a mass public shooting can be viewed as representing a comparison between 'untreated' Americans and those receiving the strongest 'dose' of the treatment by having a mass public shooting occur in their neighborhood. While a change of 0.072 appears to be a modest effect, it represents over a 20 per cent increase in the probability of supporting stricter gun laws.

Turning to the contextual controls in Table 1, we find some interesting but unsurprising effects. First, we see that residing in more population-dense, well-educated, politically liberal and racially diverse areas is associated with increased support for gun control. Countering these effects, however, we see that residing in areas with higher murder rates and more firearm stores per capita is associated with significant decreases in support for gun control. This latter effect strongly confirms the suspicion that areas with a strong 'gun culture' influence views on gun control. Indeed, moving from areas with less than 1 firearm store per 1,000 people to an area with 9.7 firearm stores per 1,000 people is associated with roughly a 0.40 decrease in the probability of preferring stricter gun control laws. This large effect is only paralleled by that of education rates, where moving from zip codes with no college-educated residents to those where every resident has at least a bachelor's degree is associated with a 0.39 increase in the

\footnotetext{
67 We should note that the results in Table 1 hold when estimating a three-level model including random intercepts for zip code and county (see Appendix Table B1). Additionally, we test for a possible nonlinear effect of proximity to a shooting and find no evidence of nonlinearity (Appendix Table B2). Furthermore, living near a mass shooting only affects gun control attitudes among those who were alive when the event occurred (Appendix Table B3), which may be interpreted as a validity check on our findings. Last, while we analyze the effect of Proximity to Shooting conditional upon the time elapsed since the shooting later in this manuscript, we do find that the results in column 1 of Table 1 hold when including Time Elapsed since the nearest shooting as a control variable (Table B4).

68 The 1984 Manley Hot Springs murders in Alaska are not classified as a mass public shooting; rather, they are classified as a spree killing, as the killer (Michael A. Silka) murdered his victims in a private location (versus a public space) over the course of several hours.
} 
TA B LE 1 The Effect of Proximity to Mass Shootings on Preferences over Gun Control Policy

\begin{tabular}{|c|c|c|c|}
\hline & $\begin{array}{c}\text { Nearest } \\
\text { shooting }\end{array}$ & $\begin{array}{l}\text { Two nearest } \\
\text { shootings }\end{array}$ & $\begin{array}{c}\text { Three nearest } \\
\text { shootings }\end{array}$ \\
\hline Proximity to Shooting & $\begin{array}{c}0.334^{*} \\
(0.172)\end{array}$ & & \\
\hline Avg. Proximity & & $\begin{array}{l}0.372 * \\
(0.148)\end{array}$ & $\begin{array}{l}0.422 * * \\
(0.158)\end{array}$ \\
\hline \multicolumn{4}{|l|}{ Contextual Controls } \\
\hline Median Income & $\begin{array}{c}0.051 \\
(0.152)\end{array}$ & $\begin{array}{c}0.052 \\
(0.151)\end{array}$ & $\begin{array}{c}0.051 \\
(0.151)\end{array}$ \\
\hline College Education & $\begin{array}{l}1.72 * * * \\
(0.219)\end{array}$ & $\begin{array}{l}1.71 * * * \\
(0.219)\end{array}$ & $\begin{array}{l}1.71 * * * \\
(0.219)\end{array}$ \\
\hline Percent Black & $\begin{array}{l}0.261 * * * \\
(0.075)\end{array}$ & $\begin{array}{l}0.254 * * * \\
(0.075)\end{array}$ & $\begin{array}{l}0.252 * * * \\
(0.075)\end{array}$ \\
\hline Republican Vote & $\begin{array}{l}-0.349 * * * \\
(0.076)\end{array}$ & $\begin{array}{l}-0.366^{* * * *} \\
(0.076)\end{array}$ & $\begin{array}{c}-0.365^{* * * *} \\
(0.076)\end{array}$ \\
\hline Murders Per Capita & $\begin{array}{c}-0.819^{* *} \\
(0.287)\end{array}$ & $\begin{array}{c}-0.850 * * \\
(0.287)\end{array}$ & $\begin{array}{c}-0.845^{* *} \\
(0.287)\end{array}$ \\
\hline Firearm Stores Per Capita & $\begin{array}{c}-59.41 * * * \\
(6.76)\end{array}$ & $\begin{array}{c}-60.04 * * * \\
(6.64)\end{array}$ & $\begin{array}{c}-60.25 * * * \\
(6.62)\end{array}$ \\
\hline Population Density & $\begin{array}{l}1.08 * * * \\
(0.230)\end{array}$ & $\begin{array}{l}1.07 * * * \\
(0.230)\end{array}$ & $\begin{array}{l}1.07 * * * \\
(0.230)\end{array}$ \\
\hline Total Population & $\begin{array}{c}0.162 * \\
(0.069)\end{array}$ & $\begin{array}{c}0.165^{*} \\
(0.069)\end{array}$ & $\begin{array}{c}0.166^{*} \\
(0.069)\end{array}$ \\
\hline Shootings in State & $\begin{array}{l}-0.017 * * * \\
(0.002)\end{array}$ & $\begin{array}{l}-0.017 * * * \\
(0.002)\end{array}$ & $\begin{array}{c}-0.017 * * * \\
(0.002)\end{array}$ \\
\hline \multicolumn{4}{|l|}{ Individual Controls } \\
\hline Education & $\begin{array}{l}0.256^{* * * *} \\
(0.035)\end{array}$ & $\begin{array}{l}0.257 * * * \\
(0.035)\end{array}$ & $\begin{array}{l}0.257 * * * \\
(0.035)\end{array}$ \\
\hline Income & $\begin{array}{l}0.124 * * \\
(0.043)\end{array}$ & $\begin{array}{l}0.124 * * \\
(0.043)\end{array}$ & $\begin{array}{l}0.124 * * \\
(0.043)\end{array}$ \\
\hline Age & $\begin{array}{l}0.011 * * * \\
(0.001)\end{array}$ & $\begin{array}{l}0.011 * * * \\
(0.001)\end{array}$ & $\begin{array}{l}0.011 * * * \\
(0.001)\end{array}$ \\
\hline Male & $\begin{array}{l}-0.787 * * * \\
(0.019)\end{array}$ & $\begin{array}{l}-0.787 * * * \\
(0.019)\end{array}$ & $\begin{array}{c}-0.787 * * * \\
(0.019)\end{array}$ \\
\hline Black & $\begin{array}{l}0.327 * * * \\
(0.037)\end{array}$ & $\begin{array}{l}0.327 * * * \\
(0.037)\end{array}$ & $\begin{array}{l}0.327 * * * \\
(0.037)\end{array}$ \\
\hline Hispanic & $\begin{array}{l}0.428 * * * \\
(0.039)\end{array}$ & $\begin{array}{l}0.428 * * * \\
(0.039)\end{array}$ & $\begin{array}{l}0.428 * * * \\
(0.039)\end{array}$ \\
\hline Asian & $\begin{array}{l}0.414 * * * \\
(0.088)\end{array}$ & $\begin{array}{l}0.428 * * * \\
(0.088)\end{array}$ & $\begin{array}{l}0.430 * * * \\
(0.088)\end{array}$ \\
\hline Homeowner & $\begin{array}{c}-0.065 * * \\
(0.023)\end{array}$ & $\begin{array}{l}-0.066^{* *} \\
(0.023)\end{array}$ & $\begin{array}{c}-0.066^{* *} \\
(0.023)\end{array}$ \\
\hline Children & $\begin{array}{c}0.015 \\
(0.023)\end{array}$ & $\begin{array}{c}0.015 \\
(0.023)\end{array}$ & $\begin{array}{c}0.015 \\
(0.023)\end{array}$ \\
\hline Military & $\begin{array}{l}-0.308^{* *} \\
(0.117)\end{array}$ & $\begin{array}{l}-0.304 * * \\
(0.117)\end{array}$ & $\begin{array}{c}-0.304 * * \\
(0.117)\end{array}$ \\
\hline Military Family & $\begin{array}{l}-0.234 * * * \\
(0.029)\end{array}$ & $\begin{array}{l}-0.233 * * * \\
(0.029)\end{array}$ & $\begin{array}{c}-0.233 * * * \\
(0.029)\end{array}$ \\
\hline Party ID & $\begin{array}{l}-1.57 * * * \\
(0.036)\end{array}$ & $\begin{array}{c}-1.57 * * * \\
(0.036)\end{array}$ & $\begin{array}{c}-1.57 * * * \\
(0.036)\end{array}$ \\
\hline Ideology & $\begin{array}{l}-2.44 * * * \\
(0.048)\end{array}$ & $\begin{array}{l}-2.44 * * * \\
(0.048)\end{array}$ & $\begin{array}{l}-2.44 * * * \\
(0.048)\end{array}$ \\
\hline Religiosity & $\begin{array}{l}0.072 * \\
(0.033)\end{array}$ & $\begin{array}{l}0.072 * \\
(0.033)\end{array}$ & $\begin{array}{l}0.072 * \\
(0.033)\end{array}$ \\
\hline South & $\begin{array}{l}0.051^{*} \\
(0.023)\end{array}$ & $\begin{array}{l}0.051^{*} \\
(0.023)\end{array}$ & $\begin{array}{l}0.050^{*} \\
(0.022)\end{array}$ \\
\hline
\end{tabular}




\section{TABLE $1 \quad$ (Continued)}

\begin{tabular}{cccc}
\hline \hline & $\begin{array}{c}\text { Nearest } \\
\text { shooting }\end{array}$ & $\begin{array}{c}\text { Two nearest } \\
\text { shootings }\end{array}$ & $\begin{array}{c}\text { Three nearest } \\
\text { shootings }\end{array}$ \\
\hline Thresholds & & & \\
Cut 1 & -3.42 & -3.40 & -3.35 \\
& $(0.179)$ & $(0.155)$ & $(0.164)$ \\
Cut 2 & -0.958 & -0.933 & -0.883 \\
\# of Individuals & $(0.178)$ & $(0.155)$ & $(0.163)$ \\
\# of Zip Codes & 53,775 & 53,775 & 53,775 \\
\hline \hline
\end{tabular}

Note: entries are unstandardized regression coefficients from multilevel regression models with random intercepts (zip) estimated using gllamm in the software package Stata ${ }^{\circledR}$. Reported significance levels are based upon two-tailed hypothesis tests. Source: 2010 Cooperative Congressional Election Study Common Content. *p $<0.05, * * \mathrm{p}<0.01, * * * \mathrm{p}<0.001$

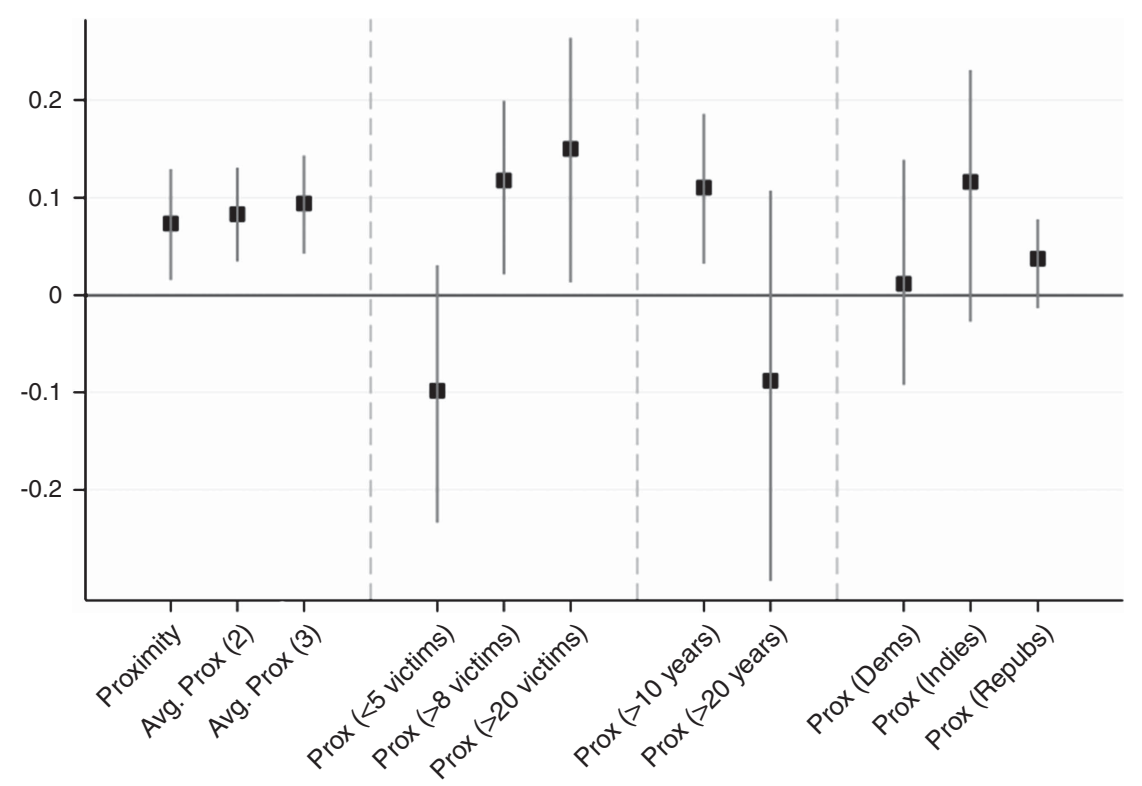

Fig. 2. Impact of proximity to a mass public shooting on change in the probability of support for gun control Note: entries are point estimates for the first difference in the predicted probability of preferring gun control laws be made 'more strict' associated with changes in proximity variables, holding all control variables at their mean values. Vertical bars intersecting point estimates are 90 per cent confidence intervals. Each listed estimate is the effect from a separate model. 'Proximity' is Proximity to Shooting, and 'Avg. Prox (2)' and 'Avg. Prox (3)' are the average proximity to the nearest two or three shooting events. Changes in the proximity variables are from minimum to maximum values. Probabilities obtained from post-estimation analysis using CLARIFY (Tomz, Wittenberg, and King 2003). Source: 2010 CCES.

probability of supporting stricter gun laws. Thus while we observe statistically significant and substantively meaningful changes in support for gun control as a function of proximity to a mass public shooting, the most powerful effects are driven by variables related to local culture, with pronounced but expected differences emerging between respondents in rural, conservative and gun-heavy areas and those residing in urban, liberal areas with few firearm stores. 
Shifting our focus to the individual-level controls, we see that gun control is more likely to be opposed by men, homeowners, individuals in the military or from military families, and by those identifying with the political right. Conversely, gun control is more likely to be supported by those of higher socio-economic status and by non-whites. In the sections that follow, we address key threats to causal inference stemming from our use of cross-sectional observational data. We demonstrate through a series of robustness checks, including the use of panel data, that our results hold.

\section{Partisan-Motivated Reasoning}

To test the partisan-motivated reasoning hypothesis, we re-estimated the model in Column 1 of Table 1 among Democrats, Independents and Republicans separately. ${ }^{69} \mathrm{We}$ present the results from this analysis in Figure 2, as well as Appendix Table B5. Figure 2 presents the change in the predicted probability of supporting stricter gun control laws associated with an increase in Proximity to Shooting among Democratic, Independent and Republican respondents. As can be seen, there are no significant differences in the effects of proximity when focusing on respondents situated at opposite ends, or in the middle, of the partisanship spectrum. ${ }^{70}$ The effect of proximity is noticeably larger for Independents, and the pattern of results suggests that the policy preferences of Independents and Republicans are more responsive to proximity to mass shootings than those of Democrats. However, rather than these effects being due to Democrats being unfazed by mass shootings, closer inspection of the data suggests they likely derive from a ceiling effect: the average value of the dependent variable (ranging from 1 to 3 ) is 2.6 among Democrats, 2.1 among Independents and 1.85 among Republicans. Thus, we observe increasing room for the movement of policy opinion as we move from Democrats to Republicans. The takeaway point of these results is that the effect of Proximity to Shooting observed in the full sample is not driven by one specific partisan group in a manner that is statistically significant. In short, we fail to uncover evidence of motivated reasoning in reactions to mass shootings.

\section{ROBUSTNESS CHECK: OMITTED VARIABLE BIAS}

One concern with our results is that, despite the inclusion of a comprehensive range of controls, the observed association between proximity to a mass shooting and gun control attitudes may nonetheless be capturing the effect of an omitted variable. Such a variable might predict variation in both where mass shootings occur and gun control attitudes. This problem subsumes other related concerns, such as residential self-selection. One plausible omitted-variable explanation for our results is the possibility that, since mass shootings are slightly more likely to occur in liberal, semi-urban areas, our findings could be due to the association of these environmental characteristics with holding liberal views on gun policy, and to those with liberal views selecting into liberal environments where mass shootings are slightly more likely to occur. It is important to reiterate that this logic highlights the importance of controlling for population density, contextual partisanship and individual political orientations, which are included in all of our analyses.

69 We define Democrats (Republicans) using the 7-point standard Party ID scale as those identifying as either a 'Strong Democrat (Republican)' or a 'Democrat (Republican)'. Independents are defined as those neither affiliating with, nor leaning towards, either party. We should note that we fail to uncover significant differences by partisanship when expanding the definition of Democrats (Republicans) to include 'leaning Democrat (Republicans)'.

${ }^{70}$ We should note that these null results replicate when using separate survey data (see Appendix Table B10). 


\section{Repeated Events, Magnitude and Recency}

One method of assessing the robustness of our findings in light of this potential omitted variable problem is to determine whether our findings vary depending upon additional factors, which according to our theory should enhance or attenuate our initial findings. Here, we explore the role of (1) repeated events, (2) the magnitude of an event and (3) the time elapsed since an event. Each of these variables in theory should relate to the salience of mass shootings, and of gun violence more generally: (1) residing near repeated mass shootings may increase the salience of gun violence over that obtained by a single event, (2) mass shootings that take a greater toll on human life may make gun violence more salient than those with fewer casualties and injuries and (3) the time elapsed since a shooting may attenuate its theorized effect on the salience of gun violence. In short, a critical question for our research is, when analyzing repeated shootings or the effect of proximity to a shooting conditional upon the number of victims or time elapsed, do the results from these more nuanced analyses 'behave' in ways that accord with our hypothesis or with the omitted variable counterhypothesis?

We begin with repeated events: according to our theory, proximity to a mass shooting should make gun violence, and the risk of victimization, more salient. One logical deduction of this expectation is that residing near more than one mass shooting should increase the 'treatment effect'. This leads to the following hypothesis:

HYPOTHESIS 3 (Repeated Events Hypothesis): Residing near multiple mass shootings will be associated with more support for gun control than that observed for residing near a single mass shooting.

Turning to the magnitude of an event, one logical deduction of our theory is that mass shootings with high casualty and injured counts should have a larger 'treatment effect' than events with fewer killed or injured. Indeed, research on other events, such as natural disasters, finds that the magnitude of an event is associated with the size of its effect on experienced stress $^{71}$ and subsequent political behavior. ${ }^{72}$ This leads to the following hypothesis:

HYPOTHESIS 4 (Event Magnitude Hypothesis): The effect of proximity to a mass public shooting on support for gun control should increase with the number of victims.

Last, when looking at the time elapsed since shootings, a final logical deduction of our theory is that the salience of gun violence aroused by mass public shootings should dissipate as time passes. Research in psychology indicates that the time horizon of events affects how people think about such events, with temporally proximate events visualized in a more concrete and visceral fashion than temporally distant events. ${ }^{73}$ This leads to the following hypothesis:

HYPOTHESIS 5 (Dissipation Hypothesis): The effect of proximity to a mass public shooting on support for gun control should dissipate as time passes.

To test the repeated events hypothesis, we constructed a variable labeled Average Proximity, which measures the average distance in miles from the centroid of respondents' zip code of residence to the two nearest mass shootings, as well as to the three nearest mass shootings. We re-estimate the model in Column 1 of Table 1 using these averaged proximity variables and present the results in Table 1, Columns 2 and 3. As can be seen, not only do the results hold, the statistical significance and size of the effects moderately increase (see Figure 2). While the

71 Freedy et al. 1994.

72 Velez and Martin 2013.

73 Trope and Liberman 2003. 


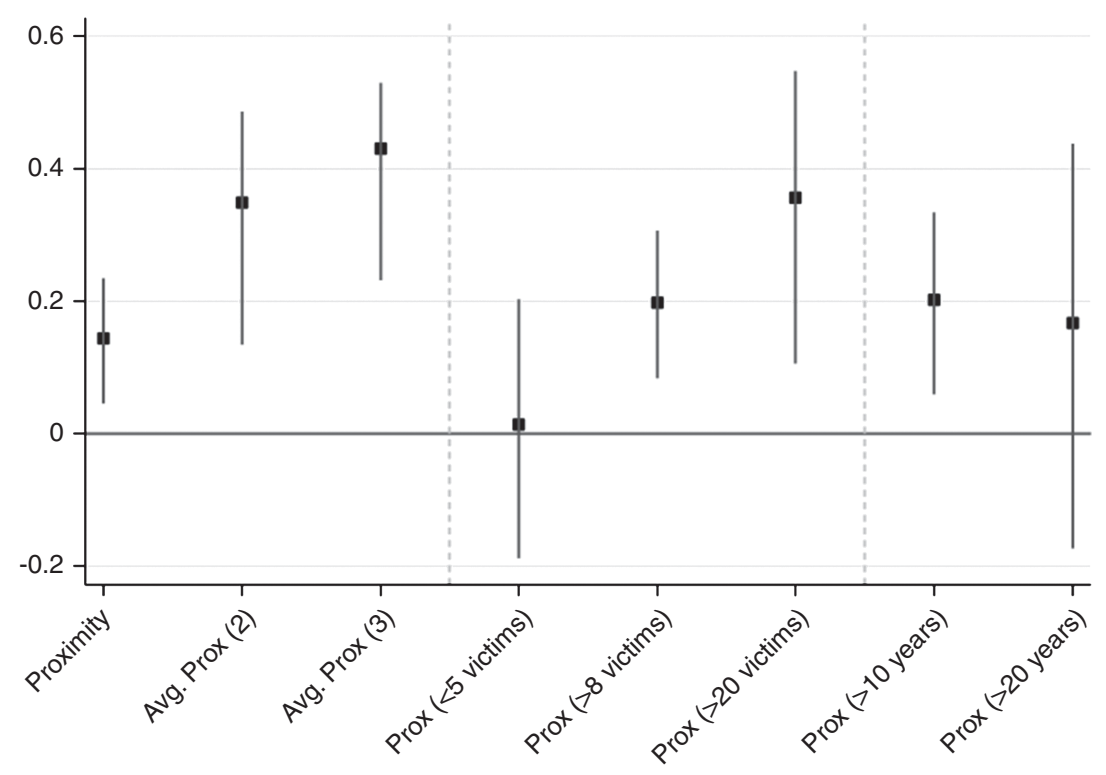

Fig. 3. Impact of change in proximity to shooting on change in probability of favoring gun control over gun rights Note: entries are point estimates for the first difference in the predicted probability of believing gun control IS more important than gun rights associated with changes in the values of key predictor variables. Vertical bars intersecting point estimates are 90 per cent confidence intervals. 'Proximity' is Proximity to Shooting, and 'Avg. Prox (2)' and 'Avg. Prox (3)' are the average proximity to the nearest two or three shooting events. Changes in the proximity variables are from minimum to maximum values. Probabilities obtained from post-estimation analysis using CLARIFY (Tomz, Wittenberg and King 2003). Source: 2010 Pew Survey.

increase is modest, the results do suggest that the impact of proximity to a mass public shooting on support for gun control strengthens when living close to more than one shooting. Moreover, when analyzing a different sample and dependent variable in the section below, we observe more drastic increases in support for gun control associated with proximity to multiple mass shootings (Table 4 and Figure 3 below). To test the Event Magnitude hypothesis, we reestimated the model in Column 1 of Table 1 at varying values of the total number of victims (killed + injured) of an event and present the results in Figure 2, as well as Appendix Table B5. Figure 2 shows that when focusing only on mass shootings with fewer than five victims $\left(25^{\text {th }}\right.$ percentile), there is no statistically significant difference in gun control preferences between those residing far versus close to the shooting. However, as we focus on events with an increasing number of total victims, ${ }^{74}$ we see that the effect of proximity gains in significance and effect size. Last, with respect to our Dissipation hypothesis, we find that the results hold when focusing on shootings occurring more than 10 years ago (that is, before 2000), ${ }^{75}$ but do

\footnotetext{
74 We should note that the cut-points used for this analysis represent meaningful percentile values of the total number of victims for the nearest mass shooting. Five victims represents the $25^{\text {th }}$ percentile value of this variable, eight victims represents the median value, and twenty victims the $90^{\text {th }}$ percentile.

75 Additional analyses reveal that this effect is restricted to respondents who report having lived at their current address at the time of the shooting (see Table B6 in Appendix B), which provides an important validity check to this result, as we are confident that these respondents received the 'treatment'. However, it is possible that individuals moving into an area after a mass shooting are impacted via 'local collective memory' (May 2000). Such a possibility, while interesting, is beyond the scope of this analysis and is best left for future research.
} 
not hold for shootings occurring more than 20 years ago (that is, before 1990) ${ }^{76}$ Thus when we focus on proximity to shootings occurring farther back in time, we fail to uncover any systematic difference in gun control attitudes between those residing close to, compared to those residing far from, the events in question. ${ }^{77} \mathrm{We}$ only find a systematic relationship between proximity and gun control attitudes when focusing on mass shootings occurring within the past 20 years.

Taken together, these findings help shore up potential doubt about the results presented in Table 1. When subjected to more nuanced analysis, we demonstrate that the pattern of results varies according to our theory: proximity to mass shootings - as well as proximity to repeated events, more horrific events and more recent events - increases the salience of gun violence, and thus garners support for gun control. These patterns of results work to render an omitted variable explanation for our initial results increasingly untenable. Indeed, the clearest way to discount this additional evidence would be to make the argument that mass shooters are not only more likely to stage their attacks in areas where residents favor gun control, but are also more likely to kill and injure more people in such areas. An omitted-variable explanation for our main results would also require arguing that attackers in 1970-90 were randomly generated across environs and/or were indiscriminate about the location of their attacks, but that this process fundamentally changed over the past two decades. We find these counterarguments untenable. For example, while mass shootings are slightly more likely to occur in populationdense, Democratic voting areas, the total number of victims of a mass shooting is entirely uncorrelated to Population Density $(\mathrm{r}=-0.05)$ and Republican Vote $(\mathrm{r}=0.08)$.

\section{Preferences Over Treatment-Irrelevant Policy Issues}

If the omitted-variable counterhypothesis is correct, and mass shootings tend to occur in areas that, for example, are more politically liberal, then the relationship we observe between proximity to shootings and gun control attitudes should also be observed for other political issues. Thus an important additional (placebo) test of the robustness of our results is whether the effects we observe for proximity to a mass shooting on gun control attitudes influence 'treatment-irrelevant' political attitudes. To test this, we estimated the model in Column 1 of Table 1 substituting for gun control four presumably treatment-irrelevant policy issues: (1) belief in Climate Change (2) support for a woman's right to an Abortion, (3) support for Gay Marriage and (4) support for granting legal status to undocumented workers living in the United States (Immigration). For full question wordings for these policy items, see Appendix A. We present the results from this analysis in Table 2.

Table 2 demonstrates that proximity to a mass shooting does not increase the holding of liberal positions on any of these other prominent issues. On the contrary, we only uncover a

76 The 10- and 20-year cut-points used in this analysis roughly correspond to the median and $75^{\text {th }}$ percentile values for the time elapsed since the nearest mass shooting. Perhaps more important than representing statistically meaningful cut-points, however, is that 10-year increments of time are inherently substantively meaningful to readers and represent intuitively comprehensible units for observing the dissipation in the effect of Proximity to Shooting over time.

77 One alternative explanation for this null result is that there is error in the measurement of Proximity to Shooting as a function of elapsed time and urbanicity. For example, the Stanford data relies on online reports, and it is possible that events occurring pre-1990 in smaller towns are more likely to have been overlooked than those occurring in larger cities. If this were the case, it would result in some unknown subset of respondents residing near a pre-1990 mass public shooting being miscoded as residing far away, yielding a test comparing those 'treated' by proximity to a shooting to a set of respondents for whom some unknown subset was also 'treated', thus biasing the estimated effect of proximity towards 0. We demonstrate in Appendix Table B7 that this null result does not change when performing median-split subsample analyses by population size or density. 
тав 2 The Effect of Proximity to Mass Shootings on Other Policy Attitudes

\begin{tabular}{|c|c|c|c|c|}
\hline & Climate change & Abortion & Gay marriage & Immigration \\
\hline Proximity to Shooting & $\begin{array}{c}-0.058 \\
(0.156)\end{array}$ & $\begin{array}{c}-0.034 \\
(0.172)\end{array}$ & $\begin{array}{c}0.223 \\
(0.210)\end{array}$ & $\begin{array}{c}-0.148 \\
(0.196)\end{array}$ \\
\hline \multicolumn{5}{|l|}{ Contextual Controls } \\
\hline Median Income & $\begin{array}{c}-0.296^{*} \\
(0.135)\end{array}$ & $\begin{array}{c}0.276^{\wedge} \\
(0.154)\end{array}$ & $\begin{array}{c}-0.316^{\wedge} \\
(0.189)\end{array}$ & $\begin{array}{c}-0.285^{\wedge} \\
(0.167)\end{array}$ \\
\hline College Education & $\begin{array}{l}0.908 * * * \\
(0.196)\end{array}$ & $\begin{array}{l}1.13 * * * \\
(0.221)\end{array}$ & $\begin{array}{l}2.50 * * * \\
(0.272)\end{array}$ & $\begin{array}{l}1.36 * * * \\
(0.240)\end{array}$ \\
\hline Percent Black & $\begin{array}{c}0.066 \\
(0.066)\end{array}$ & $\begin{array}{c}0.151^{*} \\
(0.073)\end{array}$ & $\begin{array}{c}-0.041 \\
(0.085)\end{array}$ & $\begin{array}{c}0.159^{*} \\
(0.078)\end{array}$ \\
\hline Republican Vote & $\begin{array}{c}-0.341 * * * \\
(0.069)\end{array}$ & $\begin{array}{c}-0.140^{\wedge} \\
(0.076)\end{array}$ & $\begin{array}{c}-0.268^{* *} * \\
(0.093)\end{array}$ & $\begin{array}{c}0.080 \\
(0.086)\end{array}$ \\
\hline Murders Per Capita & $\begin{array}{c}-0.628^{*} \\
(0.257)\end{array}$ & $\begin{array}{c}0.409 \\
(0.286)\end{array}$ & $\begin{array}{c}-0.087 \\
(0.345)\end{array}$ & $\begin{array}{c}0.166 \\
(0.313)\end{array}$ \\
\hline Firearm Stores Per Capita & $\begin{array}{c}-21.61 * * * \\
(6.00)\end{array}$ & $\begin{array}{c}-8.85 \\
(6.38)\end{array}$ & $\begin{array}{c}-28.70 * * * \\
(8.26)\end{array}$ & $\begin{array}{c}-1.37 \\
(7.70)\end{array}$ \\
\hline Population Density & $\begin{array}{l}0.487 * * \\
(0.179)\end{array}$ & $\begin{array}{c}0.350 \\
(0.215)\end{array}$ & $\begin{array}{c}-0.421^{\wedge} \\
(0.251)\end{array}$ & $\begin{array}{c}0.117 \\
(0.203)\end{array}$ \\
\hline Total Population & $\begin{array}{c}-0.106^{\wedge} \\
(0.061)\end{array}$ & $\begin{array}{c}0.147 * \\
(0.069)\end{array}$ & $\begin{array}{c}-0.009 \\
(0.083)\end{array}$ & $\begin{array}{c}-0.152^{*} \\
(0.076)\end{array}$ \\
\hline Shootings in State & $\begin{array}{c}0.000 \\
(0.002)\end{array}$ & $\begin{array}{l}0.014 * * * \\
(0.002)\end{array}$ & $\begin{array}{l}-0.007 * * \\
(0.003)\end{array}$ & $\begin{array}{c}0.000 \\
(0.002)\end{array}$ \\
\hline Individual Controls & & & & \\
\hline Education & $\begin{array}{l}0.356 * * * \\
(0.032)\end{array}$ & $\begin{array}{l}0.489 * * * \\
(0.035)\end{array}$ & $\begin{array}{l}0.912 * * * \\
(0.044)\end{array}$ & $\begin{array}{l}0.515^{* * * *} \\
(0.040)\end{array}$ \\
\hline Income & $\begin{array}{c}-0.099 * \\
(0.039)\end{array}$ & $\begin{array}{l}0.615^{* * *} \\
(0.043)\end{array}$ & $\begin{array}{l}0.326^{* * * *} \\
(0.052)\end{array}$ & $\begin{array}{l}0.160 \text { *** } \\
(0.048)\end{array}$ \\
\hline Age & $\begin{array}{c}-0.003^{* * * *} \\
(0.001)\end{array}$ & $\begin{array}{l}0.010^{* * * *} \\
(0.001)\end{array}$ & $\begin{array}{l}-0.008^{* * * *} \\
(0.001)\end{array}$ & $\begin{array}{l}-0.004 * * * \\
(0.001)\end{array}$ \\
\hline Male & $\begin{array}{c}-0.220 * * * \\
(0.017)\end{array}$ & $\begin{array}{c}-0.423 * * * \\
(0.019)\end{array}$ & $\begin{array}{c}-0.324 * * * \\
(0.023)\end{array}$ & $\begin{array}{c}-0.179 * * * \\
(0.022)\end{array}$ \\
\hline Black & $\begin{array}{c}-0.225^{* * * *} \\
(0.033)\end{array}$ & $\begin{array}{c}0.081^{*} \\
(0.036)\end{array}$ & $\begin{array}{c}-0.905^{* * * *} \\
(0.042)\end{array}$ & $\begin{array}{c}0.052 \\
(0.038)\end{array}$ \\
\hline Hispanic & $\begin{array}{l}0.205^{* * * *} \\
(0.035)\end{array}$ & $\begin{array}{l}-0.424 * * * \\
(0.037)\end{array}$ & $\begin{array}{l}-0.277 * * * \\
(0.046)\end{array}$ & $\begin{array}{l}0.903 * * * \\
(0.042)\end{array}$ \\
\hline Asian & $\begin{array}{l}0.251 * * * \\
(0.078)\end{array}$ & $\begin{array}{c}-0.537 * * * \\
(0.083)\end{array}$ & $\begin{array}{c}-0.705^{* * *} * \\
(0.102)\end{array}$ & $\begin{array}{c}0.040 \\
(0.089)\end{array}$ \\
\hline Homeowner & $\begin{array}{c}-0.106^{* * * *} \\
(0.021)\end{array}$ & $\begin{array}{c}0.038 \\
(0.023)\end{array}$ & $\begin{array}{c}-0.081 * * \\
(0.028)\end{array}$ & $\begin{array}{c}-0.109 * * * \\
(0.026)\end{array}$ \\
\hline Children & $\begin{array}{c}0.000 \\
(0.021)\end{array}$ & $\begin{array}{c}-0.068^{* * *} \\
(0.023)\end{array}$ & $\begin{array}{l}-0.225^{* * *} * \\
(0.028)\end{array}$ & $\begin{array}{c}-0.021 \\
(0.026)\end{array}$ \\
\hline Military & $\begin{array}{c}0.023 \\
(0.107)\end{array}$ & $\begin{array}{c}0.002 \\
(0.114)\end{array}$ & $\begin{array}{c}-0.385^{* * *} \\
(0.136)\end{array}$ & $\begin{array}{c}-0.115 \\
(0.137)\end{array}$ \\
\hline Military Family & $\begin{array}{c}-0.075^{* *} \\
(0.027)\end{array}$ & $\begin{array}{c}0.021 \\
(0.029)\end{array}$ & $\begin{array}{c}-0.083^{*} \\
(0.036)\end{array}$ & $\begin{array}{c}-0.073^{*} \\
(0.035)\end{array}$ \\
\hline Party ID & $\begin{array}{c}-2.26^{* * * *} \\
(0.034)\end{array}$ & $\begin{array}{c}-1.08 * * * \\
(0.035)\end{array}$ & $\begin{array}{c}-1.52^{* * *} * \\
(0.042)\end{array}$ & $\begin{array}{c}-1.45^{* * *} \\
(0.040)\end{array}$ \\
\hline Ideology & $\begin{array}{c}-3.41 * * * \\
(0.046)\end{array}$ & $\begin{array}{c}-2.62^{* * * *} \\
(0.048)\end{array}$ & $\begin{array}{c}-2.66^{* * * *} \\
(0.058)\end{array}$ & $\begin{array}{c}-2.29 * * * \\
(0.053)\end{array}$ \\
\hline Religiosity & $\begin{array}{c}-0.269 * * * \\
(0.030)\end{array}$ & $\begin{array}{c}-2.87 * * * \\
(0.036)\end{array}$ & $\begin{array}{c}-2.15 * * * \\
(0.042)\end{array}$ & $\begin{array}{l}0.107^{* *} * \\
(0.037)\end{array}$ \\
\hline South & $\begin{array}{c}0.018 \\
(0.020)\end{array}$ & $\begin{array}{c}0.043^{\wedge} \\
(0.023)\end{array}$ & $\begin{array}{r}-0.036 \\
(0.027)\end{array}$ & $\begin{array}{c}-0.039 \\
(0.026)\end{array}$ \\
\hline Constant & & & $\begin{array}{l}4.01 \\
(0.220)\end{array}$ & $\begin{array}{l}1.33 \\
(0.203)\end{array}$ \\
\hline Thresholds & Not Presented & Not Presented & & \\
\hline \# of Individuals & 53,725 & 53,484 & 53,833 & 53,833 \\
\hline \# of Zip Codes & 14,777 & 14,754 & 14,787 & 14,787 \\
\hline
\end{tabular}

Note: entries are unstandardized regression coefficients from multilevel regression models with random intercepts (zip) estimated using gllamm and xtlogit in the software package Stata ${ }^{\circledR}$. Reported significance levels are based upon two-tailed hypothesis tests. Source: 2010 Cooperative Congressional Election Study - Common Content. ${ }^{\wedge} \mathrm{p}<0.10,{ }^{*} \mathrm{p}<0.05,{ }^{* *} \mathrm{p}<0.01,{ }^{* * *} \mathrm{p}<0.001$ 
systematic relationship between Proximity to Shooting and preferences over gun control laws. These null findings further bolster not only our confidence in our original finding, but the causal inference we seek to make from these findings.

\section{Retest Using Panel Data}

In a final attempt to address the omitted variable counterhypothesis, as well as the more general issue of the limitations on causal inference from the use of cross-sectional data, we conducted an analysis of the 2010-12 CCES Panel Study. ${ }^{78}$ An N = 9,500 subset of the total $\mathrm{N}=55,400$ participants in the 2010 CCES was re-interviewed in October and November 2012. One benefit of using this panel is its large size and low attrition rate relative to other popular panels (for example, American National Election Study panels). Further, as noted by Ansolebehere and Schaffner, ${ }^{79}$ the demographic and partisan characteristics of the panel respondents do not significantly differ from those of the larger 2010 CCES cross-section, and few sociodemographic or partisan differences emerged in panel attrition. Important for our purposes, the 2012 re-interview asked respondents the same gun control question contained in the 2010 CCES questionnaire. Thus using this panel, we are able to assess whether changes over time in panel respondents' preferences over gun control systematically correspond to the occurrence of a mass shooting near their place of residence between panel waves.

We created a dichotomous treatment variable coded 1 if a respondent resided in a zip code within 100 miles of a mass shooting occurring between survey waves (December 2010 to September 2012), and 0 otherwise. There were 0 mass shootings in 2010 after the first CCES wave, six mass shootings in 2011, and ten in 2012 prior to the 2012 CCES re-interview (see Appendix $C$ for a list of these events). A total of 621 respondents in the panel lived 100 miles or closer to one of these sixteen events. Importantly, we restrict our analysis to respondents whose zip codes did not change between survey waves, thus helping to ensure that those coded 1 on our treatment variable received the treatment occurring in their reported area of residence between survey waves.

For our analysis, we estimated a static-score lagged dependent variable model, where we regress 2012 gun control attitudes on 2010 gun control attitudes, our dichotomous treatment variable, and the set of 2010 controls used in Table $1{ }^{80}$ We present the results from this analysis in Table 3. As can be seen, even after controlling for prior attitudes - which is expectedly one of the most powerful predictors in the model - having a mass shooting occur close by between survey waves is associated with a significant increase in the probability of favoring stricter gun control laws. Indeed, post-estimation analysis of predicted probabilities indicates a 0.06 increase in the probability of preferring stricter gun control laws as a function of having a mass shooting occur within 100 miles of one's place of residence between survey waves. While this effect appears rather modest, it is quite impressive in light of the massive variance in 2012 gun control preferences accounted for by 2010 preferences. Indeed, a minimum to maximum value change (that is, preferring less to more strict gun control laws) in 2010 reported gun control preferences is associated with nearly an 0.80 increase in the probability of reporting a preference for stricter laws in 2012.

78 Ansolebehere and Schaffner 2015.

79 Ansolebehere and Schaffner 2015.

80 As noted by Margalit (2013), the estimated effect of the treatment in this specification is identical to that obtained from a model where the dependent variable is the difference in gun control attitudes between time $(t)$ and $(t-1)$. Indeed, the results for our treatment variable are positive and significant when estimating a dynamic dependent variable model (see Appendix Table B8). 
TABLE 3 Local Occurrence of a Mass Shooting and Support for Gun Control Over Time

\begin{tabular}{lcc}
\hline \hline & $\mathrm{B}$ & $\mathrm{SE}$ \\
\hline Treatment - Local Shooting & $0.231^{*}$ & $(0.114)$ \\
Contextual Controls & & \\
\hline Median Income & -1.09 & $(0.427)$ \\
College Education & 1.26 & $(0.312)$ \\
Percent Black & 0.001 & $(0.253)$ \\
Republican Vote & -0.443 & $(0.403)$ \\
Murders Per Capita & -1.28 & $(0.766)$ \\
Firearm Stores Per Capita & -0.231 & $(0.236)$ \\
Population Density & 1.51 & $(0.872)$ \\
Total Population & 0.145 & $(0.211)$ \\
Individual Controls & & \\
2010 Attitude & $2.68^{* *}$ & $(0.052)$ \\
Education & $0.278^{*}$ & $(0.109)$ \\
Income & 0.166 & $(0.137)$ \\
Age & $0.013^{* *}$ & $(0.063)$ \\
Male & $-0.459^{* *}$ & $(0.154)$ \\
Black & $0.678^{* *}$ & $(0.147)$ \\
Hispanic & 0.161 & $(0.280)$ \\
Asian & 0.170 & $(0.082)$ \\
Homeowner & 0.030 & $(0.077)$ \\
Children & -0.012 & $(0.455)$ \\
Military & -0.694 & $(0.096)$ \\
Military Family & 0.040 & $(0.047)$ \\
Party ID & $-0.322^{* *}$ & $(0.146)$ \\
Ideology & $-2.73^{* *}$ & $(0.081)$ \\
Religiosity & -0.022 & $(0.073)$ \\
South & 0.063 & $(0.274)$ \\
Thresholds & & $(0.281)$ \\
Cut 1 & 1.02 & \\
Cut 2 & 5.27 & \\
\# Individuals & 8,371 & \\
\# Zip Codes & 5,825 & \\
\hline \hline & & \\
\hline
\end{tabular}

Note: entries are unstandardized regression coefficients from a multilevel regression model with a random intercept (zip) estimated using gllamm in the software package Stata ${ }^{\circledR}$. Reported significance levels are based upon two-tailed hypothesis tests. Source: 2010-2012 Cooperative Congressional Election Study Panel. $* \mathrm{p}<0.05, * * \mathrm{p}<0.01$

Thus we see that residing near a mass shooting between waves explains a non-negligible amount of the variance left over after explaining 2012 attitudes with prior attitudes. We should also note that we conducted a placebo test to assess whether our treatment influenced gun control preferences reported pre-treatment in 2010. The results from this test are presented in Appendix Table B9. In short, we found that while our treatment variable significantly predicted 2012 attitudes, it had no effect on 2010 attitudes.

\section{REPLICATION OF RESULTS}

An additional concern with the results presented thus far is that they largely rely on a single dataset and dependent variable, and thus may be an anomaly that fails to appear outside of the 
2010 CCES. As a further test of the robustness of our findings, we sought to replicate our results using a separate national sample of adult Americans, as well as a distinct dependent variable. For this purpose, we draw on the 2010 Political Independents Survey $(\mathrm{N}=3,500)$ conducted by the Pew Research Center for the People \& the Press. ${ }^{81}$ This survey contained nearly all the measures included in the CCES (except homeownership); thus we were able to perform a very clean replication test. The dependent variable for this analysis is a question asking respondents: 'What do you think is more important - to protect the right of Americans to own guns, OR to control gun ownership?' From this item, we constructed a dichotomous item coded (1) 'Control gun ownership' [47.5 per cent] or (0) 'Protect the right of Americans to own guns' [48.6 per cent]. ${ }^{82}$ We present the results from our analysis in Table 4 and Figure 3. For information about question wording and variable measurement, see Appendix A.

Beginning with Table 4, the results reveal that key effects observed with the 2010 CCES data replicate when focusing on a different measure of views on gun control, as well as an entirely different national sample. Interestingly, when looking at Figure 3, we see that the size of the effects of proximity to a shooting are even more dramatic in the Pew data than in the CCES data when focusing on proximity to more than one mass shooting. Further, similar to what was found with the CCES data, we see that the estimated size of the effect of proximity to a mass shooting is (1) enhanced when focusing on events with more victims and (2) attenuated when focusing on events occurring further back in time (for full results, see Appendix Table B10). While not presented in Figure 3, there were no significant differences in the effect of proximity by partisanship (see Table B10), which provides additional evidence against the Partisan-Motivated Reasoning hypothesis. These results corroborate our initial findings and strongly suggest that our findings are not an artifact of any single dataset or dependent variable.

\section{CONCLUSION}

Former President Obama personally addressed the nation more than a dozen times following a major mass public shooting during his tenure in office. What was surprisingly absent from these speeches - at least prior to the 2012 Sandy Hook mass shooting, which appears to be a watershed moment (at least for the Obama Administration) - was the issue of guns as a causal factor for the rising gun violence. ${ }^{83}$

In fact, members of Congress from both political parties have been largely reticent on the issue, reluctant to pass legislation regulating firearms for fear that they lack sufficient public support to challenge powerful gun rights' groups. Nearing the end of his time in office, the former president's attitude appears to have shifted from one of political caution to outright indignation. Visibly frustrated by the spate of recent mass shootings, particularly the shooting at Umqua Community College in Roseburg, Oregon, which wounded seventeen people (nine fatally), Obama pleaded with news organizations to push the issue to the top of the agenda and publish statistics comparing deaths in the United States from terrorist attacks to those resulting from gun violence. Obama concluded: 'This is a political choice that we make to allow this to

\footnotetext{
81 This data is available at the Pew Research Center (http://www.people-press.org/2010/09/23/independentsoppose-party-in-power-again/). This survey relied upon random digit dialing and was fielded between 25 August and 6 September. The AAPOR response rate (definition 3) was 16.5 per cent for landlines, and 11 per cent for cell phones.

${ }^{82}$ Roughly 3.9 per cent of the sample said 'don't know' or refused to answer this question.

83 E.g., see Korte 2015.
} 
tA в LE 4 The Effect of Proximity to Mass ShootingsoOn Chosen Trade-Off Between Gun Rights vs. Gun Control

\begin{tabular}{|c|c|c|c|}
\hline & $\begin{array}{l}\text { First nearest } \\
\text { shooting }\end{array}$ & $\begin{array}{c}\text { Two nearest } \\
\text { shootings }\end{array}$ & $\begin{array}{c}\text { Three neares } \\
\text { shootings }\end{array}$ \\
\hline Proximity to Shooting & $\begin{array}{c}0.630 * \\
(0.274)\end{array}$ & & \\
\hline Avg. Proximity & & $\begin{array}{c}2.11^{*} \\
(0.988)\end{array}$ & $\begin{array}{c}3.09 * \\
(1.30)\end{array}$ \\
\hline \multicolumn{4}{|l|}{ Contextual Controls } \\
\hline Median Income & $\begin{array}{c}1.45^{*} \\
(0.577)\end{array}$ & $\begin{array}{c}1.45^{*} \\
(0.579)\end{array}$ & $\begin{array}{c}1.41 * \\
(0.579)\end{array}$ \\
\hline College Education & $\begin{array}{c}0.185 \\
(0.398)\end{array}$ & $\begin{array}{c}0.187 \\
(0.398)\end{array}$ & $\begin{array}{c}0.209 \\
(0.398)\end{array}$ \\
\hline Percent Black & $\begin{array}{c}0.159 \\
(0.346)\end{array}$ & $\begin{array}{c}0.144 \\
(0.347)\end{array}$ & $\begin{array}{c}0.126 \\
(0.347)\end{array}$ \\
\hline Republican Vote & $\begin{array}{c}-0.669^{\wedge} \\
(0.376)\end{array}$ & $\begin{array}{c}-0.682^{\wedge} \\
(0.377)\end{array}$ & $\begin{array}{r}-0.652^{\wedge} \\
(0.376)\end{array}$ \\
\hline Murders Per Capita & $\begin{array}{c}-0.712 \\
(0.555)\end{array}$ & $\begin{array}{c}-0.708 \\
(0.555)\end{array}$ & $\begin{array}{c}-0.678 \\
(0.553)\end{array}$ \\
\hline Gun Stores Per Capita & $\begin{array}{c}0.457 \\
(1.91)\end{array}$ & $\begin{array}{c}0.533 \\
(1.92)\end{array}$ & $\begin{array}{c}0.641 \\
(1.92)\end{array}$ \\
\hline Population Density & $\begin{array}{l}4.60^{* *} \\
(1.54)\end{array}$ & $\begin{array}{l}4.60^{* *} \\
(1.55)\end{array}$ & $\begin{array}{l}4.52 * * \\
(1.54)\end{array}$ \\
\hline Total Population & $\begin{array}{c}0.783 * \\
(0.323)\end{array}$ & $\begin{array}{c}0.793 * \\
(0.324)\end{array}$ & $\begin{array}{c}0.797 * \\
(0.323)\end{array}$ \\
\hline Shootings in State & $\begin{array}{c}-0.006 \\
(0.010)\end{array}$ & $\begin{array}{c}-0.007 \\
(0.010)\end{array}$ & $\begin{array}{c}-0.009 \\
(0.010)\end{array}$ \\
\hline Individual Controls & & & \\
\hline Education & $\begin{array}{c}0.232 \\
(0.194)\end{array}$ & $\begin{array}{c}0.232 \\
(0.194)\end{array}$ & $\begin{array}{c}0.232 \\
(0.194)\end{array}$ \\
\hline Income & $\begin{array}{c}-0.165 \\
(0.172)\end{array}$ & $\begin{array}{r}-0.166 \\
(0.173)\end{array}$ & $\begin{array}{c}-0.165 \\
(0.172)\end{array}$ \\
\hline Age & $\begin{array}{c}-0.000 \\
(0.003)\end{array}$ & $\begin{array}{r}-0.000 \\
(0.003)\end{array}$ & $\begin{array}{r}-0.000 \\
(0.003)\end{array}$ \\
\hline Male & $\begin{array}{l}-0.842 * * * \\
(0.099)\end{array}$ & $\begin{array}{l}-0.842 * * * \\
(0.100)\end{array}$ & $\begin{array}{l}-0.841 * * * \\
(0.099)\end{array}$ \\
\hline Black & $\begin{array}{c}0.328^{\wedge} \\
(0.177)\end{array}$ & $\begin{array}{c}0.330^{\wedge} \\
(0.177)\end{array}$ & $\begin{array}{c}0.329^{\wedge} \\
(0.177)\end{array}$ \\
\hline Hispanic & $\begin{array}{l}1.01 * * * \\
(0.183)\end{array}$ & $\begin{array}{l}1.01 * * * \\
(0.183)\end{array}$ & $\begin{array}{l}1.01 * * * \\
(0.183)\end{array}$ \\
\hline Asian & $\begin{array}{l}1.11 * * \\
(0.374)\end{array}$ & $\begin{array}{l}1.10^{* * *} \\
(0.374)\end{array}$ & $\begin{array}{l}1.11 * * \\
(0.373)\end{array}$ \\
\hline Children & $\begin{array}{c}0.064 \\
(0.090)\end{array}$ & $\begin{array}{c}0.065 \\
(0.090)\end{array}$ & $\begin{array}{c}0.067 \\
(0.090)\end{array}$ \\
\hline Party ID & $\begin{array}{l}-2.00 * * * \\
(0.191)\end{array}$ & $\begin{array}{l}-2.00 * * * \\
(0.191)\end{array}$ & $\begin{array}{l}-2.00 * * * \\
(0.191)\end{array}$ \\
\hline Ideology & $\begin{array}{l}-1.45^{* * *} * \\
(0.221)\end{array}$ & $\begin{array}{l}-1.45^{* * *} \\
(0.221)\end{array}$ & $\begin{array}{l}-1.45^{* * *} \\
(0.221)\end{array}$ \\
\hline Religiosity & $\begin{array}{l}0.383^{* *} \\
(0.148)\end{array}$ & $\begin{array}{l}0.386^{* * *} \\
(0.148)\end{array}$ & $\begin{array}{l}0.386^{* *} \\
(0.148)\end{array}$ \\
\hline South & $\begin{array}{c}0.104 \\
(0.113)\end{array}$ & $\begin{array}{c}0.104 \\
(0.113)\end{array}$ & $\begin{array}{c}0.101 \\
(0.113)\end{array}$ \\
\hline Constant & $\begin{array}{c}0.743 \\
(0.387)\end{array}$ & $\begin{array}{c}-0.716 \\
(0.948)\end{array}$ & $\begin{array}{l}-1.66 \\
(1.24)\end{array}$ \\
\hline Likelihood Ratio Test & 1.56 & 1.65 & 1.58 \\
\hline \# of Individuals & 3,156 & 3,156 & 3,156 \\
\hline \# of zip codes & 2,775 & 2,775 & 2,775 \\
\hline
\end{tabular}

Note: entries are unstandardized regression coefficients from multilevel logistic regression models with random intercepts (zip) estimated using xtlogit in the software package Stata ${ }^{\circledR}$. Reported significance levels are based upon two-tailed hypothesis tests. Source: September 2010 Political Independents Survey, Pew Research Center for the People \& the Press. ${ }^{\wedge} \mathrm{p}<0.10,{ }^{*} \mathrm{p}<0.05$, $* * \mathrm{p}<0.01, * * * \mathrm{p}<0.001$ 
happen every few months in America [...] if you think this is a problem, then you should expect your elected officials to reflect your views' ${ }^{84}$

Indeed, our findings suggest that Americans - Democrats and Republicans alike - are responsive to tragic events like mass public shootings, albeit in a contextually dependent way. In contrast to claims made by vocal gun rights' advocates, we uncover evidence that citizens living near mass public shootings are more likely to prefer gun control. One unfortunate implication of our findings is that movement away from a permissive culture of gun rights towards majority support for strict gun regulations may rest upon the occurrence of more mass public shootings. To be sure, this implication places gun violence and gun control on par with policy-feedback loops observed in many other issue domains, such as environmental regulation, disaster preparedness and regulation of speculative trading - where the breaking of opinion inertia and status quo policy requires exogenous shocks that inflict pain on the nation.

Our findings also make several important contributions to the literature, and suggest important directions for future research. First, our research addresses a visible gap in the scholarly literature on the effects of mass shootings on public opinion. While there is currently a wide swath of descriptive analysis of aggregate polling data on gun legislation, there is a surprising dearth of individual-level research on the effects of mass shootings. Secondly, we provide empirical evidence of an important class of focusing events, characterized as intentional criminal acts designed to inflict mass casualties on random members of the public. Much of the extant public policy literature on focusing events concerns the effects of unintentional events such as natural disasters or environmental accidents on public opinion. Thirdly, we add to the literature on contextual effects by providing a strong empirical demonstration that Americans' preferences over gun control are responsive to proximate instances of egregious gun violence.

This contextual finding is important in light of recent work by Hopkins, ${ }^{85}$ who uncovered surprising non-responsiveness in Americans' policy attitudes to various policy-relevant factors operative in their environment. Indeed, while Hopkins finds that citizens' policy attitudes are not responsive to local pollution, income inequality or the presence of military bases, they are responsive to crime, unemployment and immigrant populations - stimuli reasoned by Hopkins to be threat laden and publicized by the mass media. Thus our findings add to these by showing an important instance of citizens' responsiveness to their surrounding environment. Finally, we stipulate a potential causal mechanism through which mass shootings may operate on gun control attitudes - namely, that these events heighten the perceived threat of gun violence, which in theory should induce greater scrutiny of policy-relevant information, increased sensitivity to risk and anxiety-reducing actions intended to mitigate the threat, among other things.

Future research should build upon our efforts by exploring the proposed causal mechanism relating to threat. More specifically, scholars could test whether exposure to nearby mass shootings heightens threat perceptions, thereby inducing anxiety. In addition, scholars could search for behavioral data linked to the gun policy domain. Of particular interest would be behavioral change resulting from residing near a mass shooting (akin to what scholars have observed in the wake of the $9 / 11$ attacks). For example, we might expect individuals living near mass a shooting to seek out information related to the issue of gun control, discuss the issue among members of their social network, potentially shift their partisan loyalties and possibly contact their legislators to press for policy change (as is often the case for family members of those injured or killed in a mass shooting). Indeed, our findings present an important but

\footnotetext{
${ }^{84} \mathrm{https} / / / w w w . w h i t e h o u s e . g o v / t h e-p r e s s-o f f i c e / 2015 / 10 / 01 /$ statement-president-shootings-umpqua-community-college-roseburg-oregon.

${ }^{85}$ Hopkins 2013.
} 
incomplete piece of a potential policy-feedback loop, as changes to public opinion may be insufficient to stimulate policy change without opinion changes translating into political action aimed at influencing policy. Thus an important step for future research in this area would be to assess the implications of our findings with respect to mass political behavior, as well as to assess whether the spatial pattern of shootings and opinion change we uncover corresponds to potential spatial variation in changes to local gun ordinances.

\section{REFERENCES}

Altheide, David L. 2009. The Columbine Shootings and the Discourse of Fear. American Behavioral Scientist 52 (1):1354-70.

Ansolebehere, Stephen. 2012. CCES Common Content 2010. Harvard Dataverse, V3. Available from hdl:1902.1/17705, accessed August 2015.

Arceneaux, Kevin, Martin Johnson, and Chad Murphy. 2012. Polarized Political Communication, Oppositional Media Hostility, and Selective Exposure. Journal of Politics 74 (1):174-86.

Atkeson, Lonna Rae, and Cherie D. Maestas. 2012. Catastrophic Politics: How Extraordinary Events Redefine Perceptions of Government. Cambridge: Cambridge University Press.

Birkland, Thomas A. 1996. Natural Disasters as Focusing Events: Policy Communities and Political Response. International Journal of Mass Emergencies and Disasters 14 (2):221-43.

—. 1997. After Disaster: Agenda Setting, Public Policy, and Focusing Events. Washington, DC: Georgetown University Press.

1998. Focusing Events, Mobilization, and Agenda Setting. Journal of Public Policy 18 (1):53-74. 2006. Lessons of Disaster: Policy Change After Catastrophic Events. Washington, DC: Georgetown University Press.

Bishop, Bradford H. 2014. Focusing Events and Public Opinion: Evidence from the Deepwater Horizon Disaster. Political Behavior 36 (1):1-22.

Bjelopera, Jerome P., Erin Bagalman, Sarah W. Caldwell, Kristin M. Finklea, and Gail McCallion. 2013. Public Mass Shootings in the United States: Selected Implications for Federal Public Health and Safety Policy, R43004. Washington, DC: Congressional Research Service.

Blair, J. Pete, and Katherine W. Schweit. 2014. A Study of Active Shooter Incidents, 2000 - 2013. Texas State University and Federal Bureau of Investigation, U.S. Department of Justice: Washington D.C.

Cho, Wendy K. Tam, and James G. Gimpel. 2012. Geographic Information Systems and the Spatial Dimensions of American Politics. Annual Review of Political Science 15:443-60.

Chyi, Hsiang Iris, and Maxwell McCombs. 2004. Media Salience and the Process of Framing: Coverage of the Columbine School Shootings. Journalism \& Mass Communication Quarterly 81 (1):22-35.

Cohen, Amy P., Deborah Azrael, and Matthew Miller. 2014. Rate of Mass Shootings Has Tripled Since 2011, Harvard Research Shows. Mother Jones, 15 October. Available from http://www.mother jones.com/politics/2014/10/mass-shootings-increasing-harvard-research, accessed August 2015.

Craighill, Peyton M., and Scott Clement. 2015. What Americans Blame Most for Mass Shootings (Hint: It's Not Gun Laws). Fix, 26 October. Available from https://www.washingtonpost.com/news/thefix/wp/2015/10/26/gun-control-americans-overwhelmingly-blame-mental-health-failures-for-massshootings/, accessed October 2015.

Cramer, Clayton E. 2006. Armed America: The Remarkable Story of How and Why Guns Became as American as Apple Pie. Nashville, TN: Thomas Nelson.

Dijksterhuis, Ap, and Henk Aarts. 2003. On Wildebeests and Humans: The Preferential Detection of Negative Stimuli. Psychological Science 14 (1):14-18.

Doherty, Carroll. 2015. A Public Opinion Trend that Matters: Priorities for Gun Policy. Fact Tank, 9 January. Available from http://www.pewresearch.org/fact-tank/2015/01/09/a-public-opiniontrend-that-matters-priorities-for-gun-policy/, accessed August 2015.

Dutton, Donald G., Katherine R. White, and Dan Fogarty. 2013. Paranoid Thinking in Mass Shooters. Aggression and Violent Behavior 18 (5):548-53. 
Enos, Ryan D. 2016. What the Demolition of Public Housing Teaches Us About the Impact of Racial Threat on Political Behavior. American Journal of Political Science 60 (1):123-42.

Enten, Harry. 2015. The Massacre In Charleston Is Unlikely to Lead to Gun Control Legislation. FiveThirtyEight, 19 June. Available from http://fivethirtyeight.com/datalab/the-massacre-incharleston-is-unlikely-to-lead-to-gun-control-legislation/, accessed August 2015.

Freedy, John R., Michael E. Saladin, Dean G. Kilpatrick, Heidi S. Resnick, and Benjamin E. Saunders. 1994. Understanding Acute Psychological Distress Following Natural Disaster. Journal of Traumatic Stress 7 (2):257-73.

Ghose, Tia. 2012. The Psychology of Mass Shootings. Live Science, 19 December. http://www. livescience.com/25666-mass-shooting-psychology.html, accessed August 2015.

Graber, Dorris A., and Johanna Dunaway. 2014. Mass Media and American Politics, 9th Edition. Thousand Oaks, CA: Sage.

Haider-Markel, Donald P., and Mark R. Joslyn. 2001. Gun Policy, Opinion, Tragedy, and Blame Attribution: The Conditional Influence of Issue Frames. Journal of Politics 63 (2):520-43.

Hofstadter, Richard. 1970. America as a Gun Culture. American Heritage 21 (6). Available from http:// www.americanheritage.com/content/america-gun-culture, accessed August 2015.

Hopkins, Daniel J. 2010. Politicized Places: Explaining Where and When Immigrants Provoke Local Opposition. American Political Science Review 104 (1):40-60.

2013. Misplaced: The Limits of Contextual Influence on Americans' Policy Attitudes. Presented at the Annual Meeting of the American Political Science Association, Chicago, IL.

Huddy, Leonie, and Stanley Feldman. 2006. Worlds Apart: Blacks and Whites React to Hurricane Katrina. Du Bois Review 3 (1):97-113.

2011. Americans Respond Politically to 9/11: Understanding the Impact of the Terrorist Attacks and Their Aftermath. American Psychologist 66 (6):455-67.

Huddy, Leonie, Stanley Feldman, Charles Taber, and Gallya Lahav. 2005. Threat, Anxiety, and Support of Antiterrorism Policies. American Journal of Political Science 49 (3):593-608.

Huddy, Leonie, Stanley Feldman, and Christopher Weber. 2007. The Political Consequences of Perceived Threat and Felt Insecurity. Annals of the American Academy of Political and Social Science 614 (1):131-53.

Huddy, Leonie, Stanley Feldman, and Erin Cassese. 2007. On the Distinct Political Effects of Anxiety and Anger. In The Affect Effect, edited by W. Russell Neuman, George E. Marcus, Ann N. Crigler and Michael MacKuen, 202-30. Chicago: University of Chicago Press.

Huddy, Leonie, Stanley Feldman, Theresa Capelos, and Colin Provost. 2002. The Consequences of Terrorism: Disentangling the Effects of Personal and National Threat. Political Psychology 23 (3):485-509.

Jacobson, Gary C. 2007. A Divider, Not a Uniter: George W. Bush and the American People. New York: Pearson/Longman.

Jaslow, Ryan. 2013. Violent Video Games and Mass Violence: A Complex Link. CBS News, 18 February. Available from http://www.cbsnews.com/news/violent-video-games-and-mass-violence-a-complexlink/, accessed August 2015.

Joslyn, Mark R., and Donald P. Haider-Markel. 2013. The Politics of Causes: Mass Shootings and the Cases of the Virginia Tech and Tucson Tragedies. Social Sciences Quarterly 94 (2):410-23.

Kam, Cindy D., and Donald R. Kinder. 2007. Terror and Ethnocentrism: Foundations of American Support for the War on Terrorism. Journal of Politics 69 (2):320-38.

Kellerman, Gabriella Rosen. 2012. Diagnosing Adam Lanza. Atlantic, 16 December. Available from http:// www.theatlantic.com/health/archive/2012/12/diagnosing-adam-lanza/266322/, accessed August 2015.

Kingdon, John W. 1984. Agendas, Alternatives and Public Policies. Boston, MA: Little Brown.

Kissner, Jason. 2016. Are Active Shootings Temporally Contagious? An Empirical Assessment. Journal of Police and Criminal Psychology 31 (1):48-58.

Korte, Gregory. 2015. 11 Mass Shootings, 11 Speeches: How Obama Has Responded. USA Today, 2 October. Available from http://www.usatoday.com/story/news/politics/2015/10/02/11-massshootings-11-speeches-how-obama-has-responded/73177526/, accessed October 2015.

Krouse, William J., and Daniel J. Richardson. 2015. Mass Murder with Firearms: Incidents and Victims, 1999-2013, R44126. Washington, DC: Congressional Research Service. 
Kunda, Ziva. 1990. The Case for Motivated Reasoning. Psychological Bulletin 108 (3):480-98.

Langman, Peter. 2009. Rampage School Shooters: A Typology. Aggression and Violent Behavior 14 (1): $79-86$.

Lankford, Adam. 2016. Are America's Public Mass Shooters Unique? A Comparative Analysis of Offenders in the United States and Other Countries. International Journal of Comparative and Applied Criminal Justice 40 (2):171-83.

Lankford, Adam, and Nayab Hakim. 2011. From Columbine to Palestine: A Comparative Analysis of Rampage Shooters in the United States and Volunteer Suicide Bombers in the Middle East. Aggression and Violent Behavior 16 (2):98-107.

Lawrence, Regina G., and Thomas A. Birkland. 2004. Guns, Hollywood, and School Safety: Defining the School-Shooting Problem Across Public Arenas. Social Science Quarterly 85 (5):1193-207.

Lodge, Milton, and Charles Taber. 2000. Three Steps Toward a Theory of Motivated Political Reasoning. In Elements of Reason: Cognition, Choice, and the Bounds of Rationality, edited by Arthur Lupia, Mathew D. McCubbins and Samuel L. Popkin, 183-213. Cambridge: Cambridge University Press.

Maguire, Brendan, Georgie Ann Weatherby, and Richard A. Mathers. 2002. Network News Coverage of School Shootings. Social Science Journal 39 (3):465-70.

Marcus, George E., W. Russell Neuman, and Michael MacKuen. 2000. Affective Intelligence and Political Judgment. Chicago: University of Chicago Press.

Margalit, Yotam. 2013. Explaining Social Policy Preferences: Evidence from the Great Recession. American Political Science Review 107 (1):80-103.

May, Reuben A. Buford. 2000. Race Talk and Local Collective Memory Among African American Men in a Neighborhood Tavern. Qualitative Sociology 23 (2):201-14.

McGinty, Emma E., Daniel W. Webster, and Colleen L. Barry. 2013. Effects of News Media Messages about Mass Shootings on Attitudes Toward Persons with Serious Mental Illness and Public Support for Gun Control Policies. American Journal of Psychiatry 170 (5):494-501.

Melzer, Scott. 2009. Gun Crusaders: The NRA's Culture War. New York: New York University Press.

Merolla, Jennifer L., and Elizabeth J. Zechmeister. 2009. Democracy at Risk: How Terrorist Threats Affect the Public. Chicago: University of Chicago Press.

Muschert, Glenn W. 2009. Frame-Changing in the Media Coverage of a School Shooting: The Rise of Columbine as a National Concern. Social Science Journal 46 (1):164-70.

Muschert, Glenn W., and Dawn Carr. 2006. Media Salience and Frame Changing Across Events: Coverage of Nine School Shootings, 1997-2001. Journalism and Mass Communication Quarterly 83 (4):747-66.

Newman, Benjamin J. 2015. A Crisis in Context Local Conditions, National Events, and Economic Policy Mood. American Politics Research 43 (6):1041-73.

Newman, Benjamin J., Hartman, Todd K, 2017. "Replication Data for: Mass Shootings and Public Support for Gun Control”, https://dx.doi.org/doi:10.7910/DVN/LL6UTV, Harvard Dataverse, V1, UNF:6: yiwg344pSa0 + HjAcW0De4A==.

Pew Research Center. 2012. Wide Partisan Gap Exists Over Gun Control. Fact Tank, 31 December. Available from http://www.pewresearch.org/daily-number/wide-partisan-gap-exists-over-guncontrol-3/, accessed August 2015.

Pierson, Paul. 1993. When Effect Becomes Cause: Policy Feedback and Political Change. World Politics 45:595-628.

PublicMind, Poll. 2015. Republicans Advocate for More Guns to Reduce Mass Shootings and Cite Terrorism as the Bigger Threat; Democrats Point to Regulation as the Best Way to Reduce Gun Violence, 20 October. Available from http://view2.fdu.edu/publicmind/2015/151020/, accessed October 2015.

Rogers, Jonathan. 2014. A Communotropic Theory of Economic Voting. Electoral Studies 36:107-16.

Schaffner, Brian, and Stephen Ansolabehere. 2015. 2010-2014 Cooperative Congressional Election Study Panel Survey. Harvard Dataverse, V3, Available from doi: 10.7910/DVN/TOE8I1, accessed August 2015.

Schlenger, William E., Juesta M. Caddell, Lori Ebert, B. Kathleen Jordan, Kathryn M. Rourke, David Wilson, Lisa Thalji, J. Michael Dennis, John A. Fairbank, and Richard A. Kulka. 2002. Psychological 
Reactions to Terrorist Attacks: Findings from the National Study of Americans' Reactions to September 11. Journal of the American Medical Association 288 (5):581-8.

Schuster, Mark A., Bradley D. Stein, Lisa H. Jaycox, Rebecca L. Collins, Grant N. Marshall, Marc N. Elliott, Annie J. Zhou, David E. Kanouse, Janina L. Morrison, and Sandra H. Berry. 2001. A National Survey of Stress Reactions After the September 11, 2001, Terrorist Attacks. New England Journal of Medicine 345 (20):1507-12.

Sears, David O. 1965. Effects of the Assassination of President Kennedy on Political Partisanship. In The Kennedy Assassination and the American Public, edited by Bradley S. Greenberg and Edwin B. Parker, 305-26. Stanford, CA: Stanford University Press.

2002. Long-Term Psychological Consequences of Political Events. In Political Psychology, edited by Kristen R. Monroe, 249-69. Mahwah, NJ: Lawrence Erlbaum Associates.

Sears, David O., and John B. McConahay. 1973. The Politics of Violence: The New Urban Blacks and the Watts Riot. Boston, MA: Houghton Mifflin.

Sears, David O., and Nicholas A. Valentino. 1997. Politics Matters: Political Events as Catalysts for Preadult Socialization. American Political Science Review 91 (1):45-65.

Sheatsley, Paul B., and Jacob J. Feldman. 1964. The Assassination of President Kennedy: A Preliminary Report on Public Reactions and Behavior. Public Opinion Quarterly 28 (2):189-215.

1965. A National Survey on Public Reactions and Behavior. In The Kennedy Assassination and the American Public, edited by Bradley S. Greenberg and Edwin B. Parker, 149-77. Stanford, CA: Stanford University Press.

Silver, Nate. 2012. Party Identity in a Gun Cabinet. FiveThirtyEight, 18 December. Available from http:// fivethirtyeight.blogs.nytimes.com/2012/12/18/in-gun-ownership-statistics-partisan-divide-is-sharp/, accessed August 2015.

Skitka, Linda J., Christopher W. Bauman, and Elizabeth Mullen. 2004. Political Tolerance and Coming to Psychological Closure Following the September 11, 2001, Terrorist Attacks: An Integrative Approach. Personality and Social Psychology Bulletin 30 (6):743-56.

Smith, Tom W. 2002. Public Opinion about Gun Policies. The Future of Children 12 (2):154-63.

Smith, Tom W., Kenneth A. Rasinski, and Marianna Toce. 2001. America Rebounds: A National Study of Public Response to the September 11th Terrorist Attacks. Chicago, IL: National Opinion Research Center at the University of Chicago.

Spitzer, Robert J. 2011. The Politics of Gun Control, 5th Edition. New York: Routledge.

Squires, Peter. 2000. Gun Culture or Gun Control? Firearms and Violence: Safety and Society. New York: Routledge.

Taber, Charles S., and Milton Lodge. 2006. Motivated Skepticism in the Evaluation of Political Beliefs. American Journal of Political Science 50 (3):755-69.

Tomz, Michael, Jason Wittenberg, and Gary King. 2003. Clarify: Software for Interprreting and Presenting Statistical Results. Journal of Statistical Software [Online]8 (1).

Traugott, Michael, Ted Brader, Deborah Coral, Richard Curtin, David Featherman, Robert Groves, Martha Hill, James Jackson, Thomas Juster, Robert Kahn, Courtney Kennedy, Donald Kinder, Beth-Ellen Pennell, Matthew Shapiro, Mark Tessler, David Weir, and Robert Willis. 2002. How Americans Responded: A Study of Public Reactions to 9/11/01. Political Science \& Politics 35 (3):511-16.

Trope, Yaacov, and Nira Liberman. 2003. Temporal Construal. Psychological Review 110 (3):403-21.

Velez, Yamil, and David Martin. 2013. Sandy the Rainmaker: The Electoral Impact of a Super Storm. PS: Political Science \& Politics 46 (2):313-23.

Wheldon, Kathleen. 2015. Despite More Shootings, Americans Are Less Supportive of Tougher Gun Control. Huffington Post, 31 August. Available from http://www.huffingtonpost.com/kathleenweldon/shootings-guns-and-public_b_8065682.html, accessed October 2015.

Wong, Cara J. 2010. Boundaries of Obligation in American Politics: Geographic, National, and Racial Communities. Cambridge: Cambridge University Press.

Wozniak, Kevin H. 2015. Public Opinion About Gun Control Post-Sandy Hook. Criminal Justice Policy Review 28 (3):255-78. 